\title{
Bacteriophages of Shiga Toxin-Producing Escherichia coli and Their Contribution to Pathogenicity
}

\author{
Lorena Rodríguez-Rubio $^{1}\left(\mathbb{D}\right.$, Nadja Haarmann $^{2}$, Maike Schwidder ${ }^{2}$, Maite Muniesa ${ }^{1}\left(\mathbb{D}\right.$ and Herbert Schmidt ${ }^{2, *}(\mathbb{C}$ \\ 1 Department of Genetics, Microbiology and Statistics, University of Barcelona, Diagonal 643, \\ 08028 Barcelona, Spain; lorenarodriguez@ub.edu (L.R.-R.); mmuniesa@ub.edu (M.M.) \\ 2 Department of Food Microbiology and Hygiene, Institute of Food Science and Biotechnology, \\ University of Hohenheim, 70599 Stuttgart, Germany; nadja.haarmann@uni-hohenheim.de (N.H.); \\ maike.schwidder@uni-hohenheim.de (M.S.) \\ * Correspondence: herbert.schmidt@uni-hohenheim.de; Tel.: +49-711-459-2-2305
}

Citation: Rodríguez-Rubio, L.; Haarmann, N.; Schwidder, M.;

Muniesa, M.; Schmidt, $\mathrm{H}$.

Bacteriophages of Shiga

Toxin-Producing Escherichia coli and Their Contribution to Pathogenicity. Pathogens 2021, 10, 404. https://

doi.org/10.3390/pathogens10040404

Academic Editor: Peter Speck

Received: 28 January 2021

Accepted: 24 March 2021

Published: 29 March 2021

Publisher's Note: MDPI stays neutral with regard to jurisdictional claims in published maps and institutional affiliations.

Copyright: (c) 2021 by the authors. Licensee MDPI, Basel, Switzerland. This article is an open access article distributed under the terms and conditions of the Creative Commons Attribution (CC BY) license (https:// creativecommons.org/licenses/by/ $4.0 /)$.

\begin{abstract}
Shiga toxins (Stx) of Shiga toxin-producing Escherichia coli (STEC) are generally encoded in the genome of lambdoid bacteriophages, which spend the most time of their life cycle integrated as prophages in specific sites of the bacterial chromosome. Upon spontaneous induction or induction by chemical or physical stimuli, the st $x$ genes are co-transcribed together with the late phase genes of the prophages. After being assembled in the cytoplasm, and after host cell lysis, mature bacteriophage particles are released into the environment, together with Stx. As members of the group of lambdoid phages, Stx phages share many genetic features with the archetypical temperate phage Lambda, but are heterogeneous in their DNA sequences due to frequent recombination events. In addition to Stx phages, the genome of pathogenic STEC bacteria may contain numerous prophages, which are either cryptic or functional. These prophages may carry foreign genes, some of them related to virulence, besides those necessary for the phage life cycle. Since the production of one or more Stx is considered the major pathogenicity factor of STEC, we aim to highlight the new insights on the contribution of Stx phages and other STEC phages to pathogenicity.
\end{abstract}

Keywords: Stx phages; STEC; Shiga toxins; lambdoid prophages; pathogenicity; virulence factors; antibiotic resistance genes

\section{Introduction}

Soon after the first reported outbreak with pathogenic Shiga toxin-producing E. coli (STEC) O157:H7 (syn. enterohemorrhagic E. coli (EHEC)) in Oregon and Michigan, USA, in 1983, the ability of these pathogens to produce Stx (syn. Shiga-like toxin, verocytotoxin, verotoxin) was demonstrated to be encoded by bacteriophages [1]. Following this observation, Alison O'Brien's group genetically and morphologically characterized two Stx converting phages induced from E. coli O26 and E. coli O157:H7 strains [2]. Phages H19J and 933J showed a typical head-tail structure with short tails. Some years later, Huang et al. demonstrated the homology of Stx1-converting bacteriophage H19-B to phage lambda by southern blot hybridization and restriction analysis [3]. During the following years, methodological developments allowed for an accurate characterization of Stx phages, making it clear that these phages comprise a family of genetically heterogeneous members [4-9]. Whole genome sequencing yielded the sequence data of hundreds of pathogenic STEC genomes in the National Center for Biotechnology Information (NCBI) database (https://www.ncbi.nlm.nih.gov/genome/browse\#!/prokaryotes/167/, accessed on 26 March 2021), which confirmed the heterogeneity of Stx phage genomes. These differences, in turn, influence the bacterial genome structure and its functionality [10]. Furthermore, the prophage sequences demonstrate that all Stx phages conserve a basic lambdoid structure that is discussed below. 


\section{Morphology, Genetic Structure and Integration Sites of Stx Phages}

All known Stx phages are double-stranded DNA-phages with a functional genetic organization similar to that of the archetypical phage lambda, which is one of the best studied E. coli phages [11,12]. Stx phages share a common head-tail structure ranging from icosahedral or elongated heads to contractile, non-contractile, or short tails with or without tail fibers [9,13-19].

Although all Stx phages share the same lambda-like genetic structure, significant variations in their genetic composition occur and genome sizes ranging from 28.7 to $71.9 \mathrm{~kb}$ have been described [17,20-22].

According to their morphological structure, Stx phages are classified into different families of the order Caudovirales. For example, the Stx2a phage 933W of the E. coli O157:H7 strain EDL933 consists of a short tail and regular hexagonal head and belongs to the Podoviridae family [18], whereas the prototype Stx1 phage H19-B [3,15] consists of an elongated head with a long non-contractile tail compatible with phages of the Siphoviridae family. While most of the characterized Stx2 phages belong to the family Podoviridae [9,23,24], only a few reports exist where Stx phages have been described as members of the family Myoviridae [25].

A large majority of short-tailed Stx phages (among them the Stx2 phages $933 \mathrm{~W}$ and Sp5 of E. coli O157 strains EDL933 and Sakai) use highly conserved tail spike proteins for host recognition [23]. Sequence homologues of the tail spike protein gene of short-tailed Stx phages were also found in the genomes of Stx phages of the Siphoviridae and Myoviridae family [26]. Essential for phage adsorption is the highly conserved receptor protein YaeT (also known as BamA) on the bacterial cell surface and its orthologues, which ensure the spread among various members of the family of Enterobacteriaceae [23,27]. Two other potential receptor proteins, FadL and LamB, have been described for phages Stx $2 \Phi-I$ and Stx2 $\Phi-I I$, isolated from clinical STEC strains [28], but they could not be confirmed in later studies as functional receptors for phage Sp5 of the E. coli O157 strain Sakai [27].

As lambdoid phages, Stx phages share a general genetic structure with immediate early, delayed early, and late phase genes. All of them possess a common regulatory system that includes different variants of $c r o, c I, N$, and $Q$ genes, which are involved in the regulation of the phage entering the lysogenic or lytic life cycle $[19,20,29,30]$. All Stx phages known so far show a conserved location of the stx genes in the late regulatory region of the prophage genomes (Figure 1) $[8,11,19,31,32]$. More precisely, stx genes are located downstream of the gene encoding the antiterminator protein $Q$ and upstream of the lysis cassette consisting of $S, R$, and $R z$, and are thereby under control of the late promoter $p_{R^{\prime}}[7,8,18,19,33]$ (Figure 1). However, the genomic region between the antiterminator $Q$ gene and stx has been shown to be diverse among Stx phages of the same subtype, and is therefore supposed to have an influence on the Stx expression level [34]. Variations of the $Q$ gene have also been reported, which are thought to have a minor impact on Stx expression and correlate loosely with a clinical or bovine origin of the strains [35]. It is hypothesized that $Q_{21}$ genes similar to the one of $\varphi 21$ are often associated with lower Stx expression than the $Q_{933}$ gene variants of phage $933 \mathrm{~W}[36,37]$. Nevertheless, these results are not completely clear and could not be supported by other studies [38]. Most probably, there are various unidentified factors also contributing to the level of Stx expression [35,38].

Genomic differences have also been reported for the early regulatory regions of Stx phages. For example, Stx 2 phage $933 \mathrm{~W}$ contains three operator sites in the right operator region, but only two operator sites in the left operator region, which is different from phage lambda and most other lambdoid phages [39]. In contrast, Stx1 phage H-19B contains four operator sites in the right operator region [40]. It is not well understood how these differences in the early regulatory region affect repressor/operator interactions and, thereby, expression of Stx. However, it was demonstrated that spontaneous induction occurs more readily in Stx phages than in lambdoid prophages without stx genes $[39,41]$.

During the lysogenic state, transcription of most phage genes is mostly silenced by the $\mathrm{CI}$ repressor binding at the operators within the early regulatory region [42]. Although expression of certain Stx phage genes during the lysogenic state has been reported [43], 
it was attributed to a small subset of cells that spontaneously induced the lytic cycle. Thereby, the transcription of phage genes is terminated at $t_{\mathrm{R}^{\prime}}$ located directly downstream of $p_{R^{\prime}}$, thus preventing the transcription of st $x$ genes. Upon phage induction, a cascade of regulatory events leads to the expression of early and late antiterminator proteins $\mathrm{N}$ and $\mathrm{Q}$, respectively, allowing polymerase read-through of downstream terminators [30] (Figure 1).

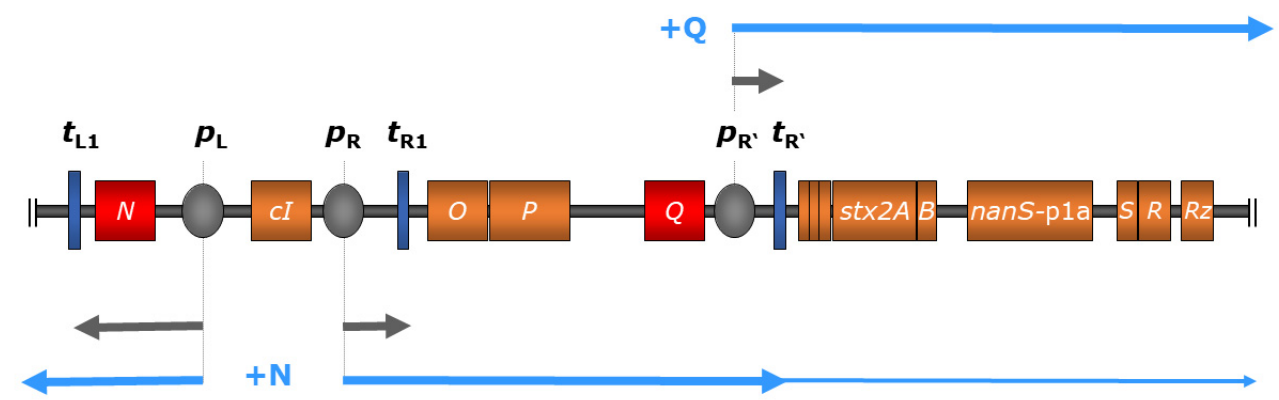

Figure 1. Regulation scheme of stx expression in bacteriophage $933 \mathrm{~W}$ of E. coli O157:H7 strain EDL 933 comprising relevant genes (colored in orange) and regulatory elements (not to scale), modified from Wagner and Waldor 2002 [30]. During the lysogenic state (indicated in grey arrows), transcription is inhibited through binding of the $c$ I-encoded repressor protein to operator sites of the early promoters $p_{\mathrm{L}}$ and $p_{\mathrm{R}}$ (colored in grey); transcription is also terminated by downstream terminators (dark blue). Upon phage induction, autocleavage of the $c$-encoded repressor protein allows transcription at $p_{\mathrm{L}}$, resulting in the production of phage-encoded antiterminator protein $\mathrm{N}$ (red), which enables polymerase read-through at downstream terminators including $t_{\mathrm{L} 1}$ and $t_{\mathrm{R} 1}$. This, in turn, leads to the expression of the late-phase antiterminator $\mathrm{Q}$ (red), which facilitates transcription initiating at the late-phase promoter $p_{R^{\prime}}$, transcending terminator $t_{R^{\prime}}$, and resulting in the expression of downstream genes including stx (indicated in light blue arrows). Additionally, the expression of $O$ - and $P$-encoded phage replication products leads to increased Stx production by amplifying stx copy numbers [30,39].

Interestingly, a continuous transcription activity at phage late promoter $p_{R^{\prime}}$, which is terminated directly downstream at $t_{\mathrm{R}^{\prime}}$, generates a short RNA byproduct under lysogenic conditions [44]. It was demonstrated that this regulatory small RNA represses expression of Stx1 under lysogenic conditions and modulates host fitness [45].

Stx phages can harbor a number of additional genes acquired by horizontal gene transfer $[9,20]$. These so-called morons ("more-on" refers to additional DNA on the phage genomes) are mainly found in the late phage region and usually have a different nucleotide composition compared to the rest of the phage genome. Furthermore, morons may have their own promoter and terminator sequences, so the transcription is independent from phage induction. These genes have no obvious function for the phage but are typically beneficial for the host $[9,46]$.

The STEC genome can contain various Stx prophages and diverse non-Stx prophages [47]. Several strains naturally carry more than one Stx phage and double, or even triple, lysogens of the same Stx phage can be experimentally produced [48,49]. Stx phage integrases seem to have evolved to recognize different insertion sites within the bacterial chromosome. Thus, although each Stx phage integrates preferentially in one particular site, the integrase is able to recognize secondary sites for the phage genome integration if this preferred site is occupied or deleted [50].

Several chromosomal insertion sites have been described for Stx phages: yehV encoding a regulator for curli expression [51,52], wrbA encoding the Trp repressor-binding protein [18], yecE whose function is unknown [32], $s b c B$ encoding an exonuclease [17,53], Z2577 encoding an oxidoreductase [54], ssr A encoding a tmRNA [55], prfC encoding a peptide chain release factor [56], argW encoding a tRNA [57], and the intergenic region between torS and torT genes [56]. In addition, a study by Steyert et al. revealed five novel insertion sites (potC, yciD, ynfH, serU, yjbM) in Locus of Enterocyte Effacement (LEE)-negative 
STEC isolates that had not been reported to be occupied by Stx phages before [58]. Several new insertion sites have been described for Stx phages carrying the novel Stx2 subtypes Stx2h and Stx2k [21,59]. The Stx2k prophage was found to be integrated adjacent to the $y j j G$, encoding a nucleotide phosphatase $[59,60]$. Different insertion sites were described for the Stx $2 \mathrm{k}$ phages including $d u s A$, which encodes a tRNA dihydroxyuridine synthase A [61], yccA, a predicted transmembrane protein [62,63], and the zur gene encoding a zinc uptake regulator $[21,64]$.

Unlike phage lambda, Stx phages can occur as multiple isogenic prophages in the bacterial chromosome at different insertion sites $[50,65]$. Whereas phage lambda leads to host immunity, Stx phages are able to evade superinfection immunity $[48,49,66]$. For example, Stx 2 phage $\Phi 24_{\mathrm{B}}$ was shown to integrate into a single host at least three times and furthermore, it was demonstrated that the frequency of multiple lysogens increased with each integrated prophage $[9,67]$. Different results were reported concerning the influence of multiple lysogens on the toxin expression level: interestingly, experiments with a double isogenic Stx 2 phage showed an enhanced production level of Stx [65], whereas other studies with two different Stx2 prophages showed reduced toxin levels $[48,68]$.

\section{Induction, Expression and Release of Stx}

When Stx phages choose the lysogenic pathway, phage DNA is inserted into the E. coli chromosome, forming a prophage that is replicated together with the bacterial chromosome, transferred to the bacterial progeny by vertical gene transfer and maintained for many cell generations. When diverse environmental conditions threaten the viability of the bacterial cell, these stimuli trigger the SOS response, activating the induction of the prophage. Several of these stimuli have been identified including changes in $\mathrm{pH}$, particularly low $\mathrm{pH}$ [69], presence of iron [70], presence (or absence) of ions, which also confers a role on chelating agents such as EDTA and sodium citrate [71,72], several antibiotics including growth promoters $[73,74]$, and other agents causing DNA damage such as mitomycin C or hydrogen peroxide [75-77].

After induction, prophages are excised from the chromosome. The viral DNA, which exists as a separate molecule within the bacterial cell, then replicates separately from the host bacterial DNA as an extrachromosomal element [78]. It has been found that stx can be detected in a circular, extrachromosomal state when the non-chromosomal elements are analyzed by southern blot after a PFGE of S1-digested DNA from STEC strains [79]. Moreover, circularized plasmid-like pseudolysogens of Stx phages have been observed in studies of integration of Stx phage $\Phi 24 B$ [67]. Plasmids derived from Stx phages have also been used to study the efficiency of DNA replication of lambdoid phages [78].

During replication, expression of the phage structural proteins and Stx takes place. The structural components are assembled into new Stx phage particles, which are released from the cell by the action of phage lytic proteins expressed at the end of the induction process. These proteins cause the disruption of the bacterial host cell, allowing the release and spread of Stx $[8,42]$, which is the main virulence factor determining the severity and lethality of the STEC infection [80].

Stx can also be released by outer membrane vesicles (OMV) [81-84]. These OMVs protect Stx and other proteins from degradation by proteases and mask its presence in cytotoxicity or bead-enzyme-linked immunosorbent assays [81]. It was shown that OMVs from the hypervirulent O104:H4 outbreak strain are also internalized by intestinal epithelial cells despite not expressing the typical $\mathrm{GB}_{3}$ receptor [84]. A major study by Bielaszewska et al. also described this internalization strategy. Briefly, vesicles were taken up via dynamin-dependent endocytosis, followed by retrograde transport of the Stx holotoxin in early endosomes toward the Golgi complex and endoplasmatic reticulum. The enzymatic active Stx2A subunit could then be transported to the cytosol and bind to the ribosome [83].

In addition to Stx release, the new Stx phages are set free, which allows the dissemination and acquisition of the stx gene among susceptible cells (E. coli or even other genera) present in the same biome [85], contributing to the evolution of STEC [86]. In this context, 
stx genes have been detected in Citrobacter freundii [87], Enterobacter cloacae [88], Shigella sonnei [89], and Aeromonas spp. [90].

The effective production of Stx 2 is always dependent on phage induction, whereas Stx release is dependent on cell lysis [42]. However, a different situation can be observed for Stx 1 , encoded by Stx 1 phages $[58,70,91]$. The expression of Stx 1 is caused by two independent promoters. The first is a late phage promoter $p_{R^{\prime}}$ dependent on phage induction (as for Stx2 phages), which allows the expression and release of the toxin by the phage-mediated cell lysis. The second is a specific Stx 1 promoter containing a binding site for Fur protein, which makes complexes with iron. Thus, in the presence of iron, Fur blocks Stx1 expression, while in the absence of iron, this repression does not occur and Stx1 is expressed. This situation is entirely independent of phage induction, and Stx 1 levels of production are similar to those observed under conditions where the Stx1 phage is not induced [70]. The main consequence of the phage-independent expression of Stx1 is that cells expressing Stx1 can avoid cell lysis, enhancing their survival. Fewer strains producing Stx1 phages means a lower occurrence of free Stx1 phages compared with Stx2 phages, which has been confirmed by analyzing free Stx1 vs. Stx2 phages in extracellular biomes [91].

In any case, Stx2 or Stx1 phage induction poses a serious threat for the survival of the STEC population, which must sacrifice its prevalence for the sake of increasing its virulence. The solution of the paradox presented by Stx as a virulence factor that forces phage activation and cell lysis in order to be expressed and released, is obtained when considering the heterogeneity of the STEC population. In a bacterial population, not all bacterial cells behave synchronously since they are not in the same physiological or growth state, therefore not all of them activate phage induction simultaneously. Thus, one subpopulation will induce Stx phages, producing new virions and expressing the toxin, while another subpopulation remains in the lysogenic state, enhancing its survival and becoming the population's reservoir [92]. Although the mechanism dealing with the differences between the inducible and the non-inducible stage have not yet been completely elucidated, the growth state seems to play a role. Cells reaching the stationary phase prevent induction better than cells in the exponential phase. The RpoS factor, highly expressed in E. coli cells in the stationary phase, was shown to cause a dramatic delay in Stx phage induction within the E. coli population, and overexpression of RpoS resulted in a large number of E. coli cells that do not induce the Stx prophage [92]. In contrast, in E. coli, lambda prophage induction has been shown to be regulated by the OxyR protein [93].

The differential induction of Stx phages within the STEC population is indeed considered an altruistic strategy shown by a fraction of the STEC cells, rendering the expression of Stx a positive force for the benefit of the whole population [94]. It has been seen in cells spontaneously inducing Stx phages [41] under natural conditions but also in the presence of $\mathrm{H}_{2} \mathrm{O}_{2}$, which is produced by neutrophiles during STEC infection in the human body [94].

\section{Stx Phages as Pathogenic Principle}

In addition to stx, many additional genes have been described in Stx prophage genomes, which may contribute to pathogenicity and virulence, but also to the competitiveness with other gut bacteria in the human host. There are a number of reviews and book chapters that have described the role of some genes in the Stx phages that contribute to regulating pathogenicity in STEC $[9,10,46,71,95]$, and therefore, their structure, function, and roles in pathogenicity will not be reviewed here.

However, there is one newer gene family that is worth describing, since it is present in a number of Stx and non-Stx phages of pathogenic STEC. In preliminary work, an open reading frame (ORF) located downstream of the stx operon in the genome of phage $933 \mathrm{~W}$ of E. coli O157:H7 and other relevant STEC serotypes was identified [96]. This ORF (z1466) could be induced in microarray experiments together with stx upon norfloxacin treatment of E. coli O157:H7 strain EDL933 [97]. When cultured in simulated colonic environmental medium (SCEM), a 40-fold expression of the corresponding protein P42 was observed [98]. Comparative analyses showed that the gene z1466 is highly homologous to a Neu5,9 $\mathrm{Ac}_{2}-$ 
esterase gene from E. coli that has already been in the focus of several studies $[99,100]$. By molecular and biochemical analyses, it was shown that z1466 indeed encodes a Neu5,9 $\mathrm{Ac}_{2}-$ acetylesterase, with an active esterase function similar to the chromosomally-encoded NanS, present in many E. coli strains [101]. Moreover, the gene was significantly longer than nanS and contained regions without homology to any known genes [102]. The function of the esterase as well as the role of seven vs. $10 \mathrm{Neu} 5,9 \mathrm{Ac}_{2}$ acetylesterases (NanS-p) from E. coli O157:H7 strain EDL933, and of five NanS-ps from E. coli O104:H4 strains C227-11 ccu were analyzed, and it was shown that all these enzymes were encoded in prophage genomes that produced active esterases from their corresponding nanS-p alleles [101,103]. These results were in concordance with Eric Vimr's early work [99] showing that cleavage of the $\mathrm{O}$-acetyl residues from $\mathrm{Neu} 5,9 \mathrm{Ac}_{2}$ allowed the lysogen to grow with $\mathrm{Neu} 5,9 \mathrm{Ac}_{2}$ as a single carbon source. Furthermore, experiments with bovine maxillary gland mucin revealed the cleavage of mono, di, and triacetylated $O$-glycans by the NanS-p enzymes [102]. Similar experiments with the 2011 outbreak strain O104:H4 C227-11 $\varphi$ cu revealed comparable results [103]. Taken together, the experiments have shown that these phage-encoded NanS$p$ enzymes can be used by pathogenic STEC strains to utilize mucin components for their growth, conferring an advantage to the lysogens [100,102-104] (Figure 2).

The fact that nanS- $p$ genes are generally located in phage genomes and that Neu5,9$O$-acteylesterases are able to cleave $O$-acetyl residues from sugar moieties [105] raises the question whether this enzyme may play a role in the phage replication cycle itself and consequently could contribute to the STEC infection process. A very interesting aspect of the NanS-p function came from the structural annotation by homology modeling of the esterase domain and crystal structure analysis of the C-terminal domain of the conserved carbohydrate esterase vb_24B_21 from the Stx phage $\varphi 24_{\mathrm{B}}$, which is homologous to nanS$\mathrm{p}$ [104]. The authors proposed a lectin-like, jelly-roll sandwich-fold in the C-terminus with a proposed function in carbohydrate-binding for this domain [104]. It was hypothesized that such a structure could target the enzyme to its substrate to increase the local concentration and to improve catalysis, as shown for similar enzymes [106,107]. Up to now, there is no experimental evidence that this is the case for NanS-ps of pathogenic E. coli. However, carbohydrate-binding may be advantageous for pathogenic E. coli, which can use mucins with a particular carbohydrate structure as the substrate.

Another possibility is that NanS-ps could also be an advantage for the phages itself by enhancing the recognition of phage receptors at the bacterial outer membrane surface. In Gram-negative bacteria, phages have to encounter the LPS, which may function as an initial binding site for infection [108-110]. $O$-antigens of the lipopolysaccharide may be acetylated, and cleavage of these $O$-acetyl groups may facilitate phage binding $[109,111]$ as well as subsequent traversing of the LPS to reach the specific receptor sites located at the outer membrane [112]. Whether NanS-ps may play a role for the attachment of Stx phages remains to be elucidated. 


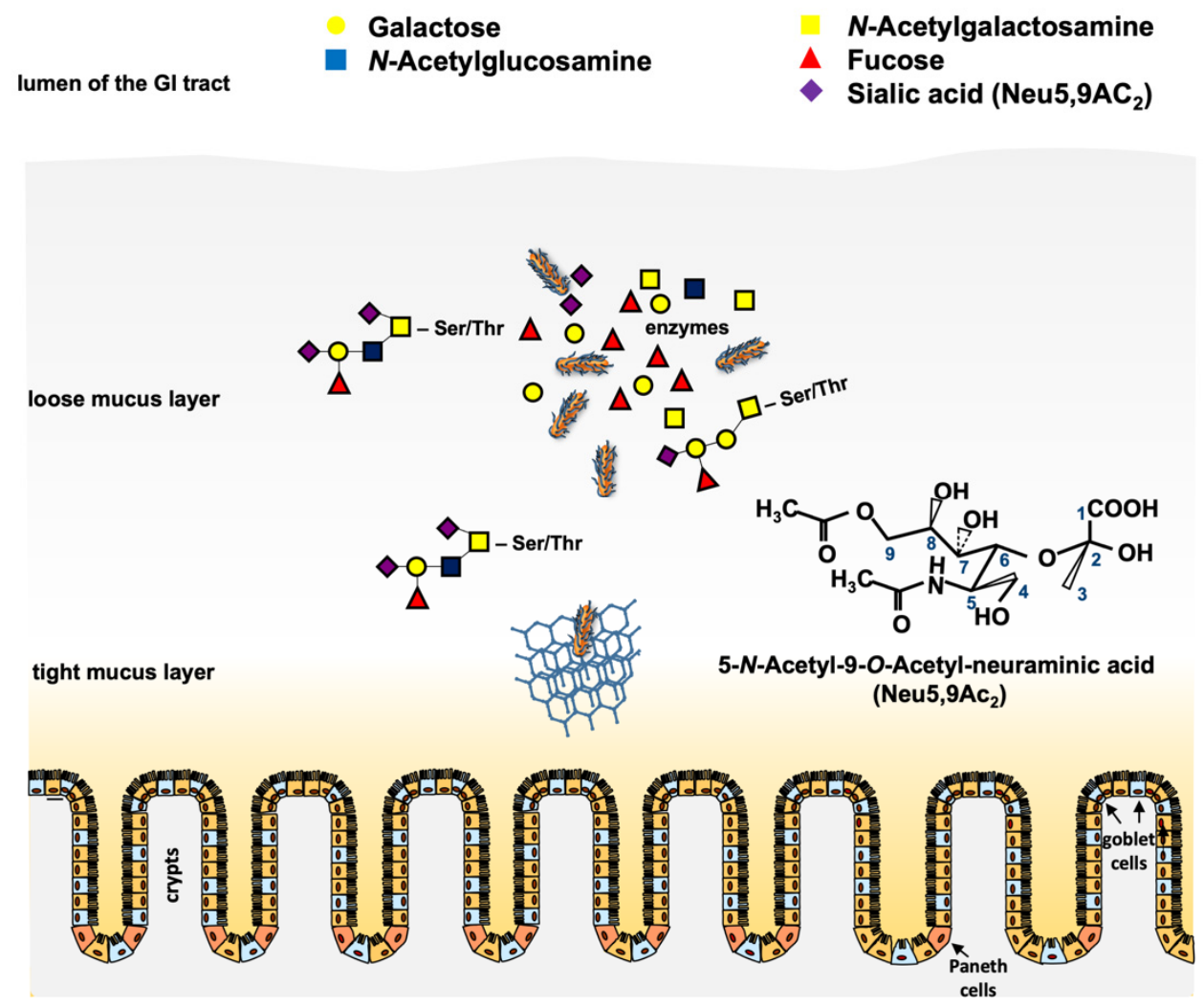

Figure 2. Scheme of putative functions of the phage-encoded $O$-acetyl esterase in the large intestine. Pathogenic STEC cells have to traverse the loose and the tight mucus layer to reach the epithelium for adherence and colonization. Mucinases and other proteases play a role in that process. Cleavage of $\mathrm{O}$-acteyl residues from terminal $\mathrm{O}$-glycans (e.g., Neu5,9 $\mathrm{Ac}_{2}$ ) by chromosomal and phage-encoded $\mathrm{O}$-acetyl esterases results in deacetylated free sialic acids such as $\mathrm{N}$-acetyl neuraminic acid, which can be metabolized by the bacteria [113]. The chemical structure of $\mathrm{Neu}_{1}, 9 \mathrm{Ac}_{2}$ is shown. Honeycomb structure $=$ mucin network. Paneth cells and goblet cells are indicated.

\section{New Stx Phages}

Aside from the two main immunologically distinct toxin types Stx1 and Stx2 [114], several subtypes have been described according to the nomenclature proposed by Scheutz et al. [115]. Whereas Stx1 presents the more homogeneous group consisting of subtypes Stx1a, Stx1c, and Stx1d, the Stx2 group is more heterogeneous and also more frequently associated with severe forms of diseases such as hemorrhagic colitis or HUS $[116,117]$. Additionally, the level of Stx expression has been shown to be correlated with different Stx subtypes and phages [118]. In a study by Fitzgerald et al., using an E. coli O157 strain harboring both Stx2a and Stx2c phages, it was demonstrated that Stx2a was induced more rapidly and to higher levels than Stx2c [119]. Whereas Stx2c phages seem to be highly homogeneous, as reported by Ogura et al., during a comprehensive analysis of Stx2 phages in 123 EHEC O157 strains, Stx2a phages could further be subtyped according to their replication proteins. The respective Stx2a subtypes also correlated with the level of Stx2a expression in the host strains [68].

In addition to the well-known subtypes Stx2a, Stx2b, Stx2c, Stx2d, Stx2e, Stx2f, and Stx $2 g$, several phages harboring new st $x$ subtypes were described. For example, the novel Stx2 subtype h, which was found in STEC strains isolated from intestinal tracts of healthy marmots in China. The Stx $2 \mathrm{~h}$ prophage was reported to be $49,713 \mathrm{bp}$ in size [59]. Sequence analysis revealed 93 predicted coding sequences (CDSs), out of which 37 were hypothetical proteins or mobile elements with unknown function, while phage-specific genes, encoding proteins responsible for integration, transcriptional regulation, and lysis, were found in accordance to other Stx2 phages [59]. 
A further Stx 2 subtype, Stx2i, was described in STEC isolates recovered from shrimps and bivalves, but no further information concerning the genomic characteristics of the respective phages was given $[120,121]$. The same applies to the subtype Stx $2 j$, which was mentioned in a publication by Yang et al., but without further information [21]. The latest subtype described so far, Stx2k, was identified in E. coli strains isolated from different sources in China including humans, animals, and raw meat [21]. Interestingly, the isolated E. coli strains, which carried the Stx2k phage, showed considerable heterogeneity in serotype, genome sequence, and virulence gene profile. One of the analyzed STEC strains even harbored the plasmid-encoded heat-stable enterotoxin gene sta as well as two copies of enterotoxin gene $s t b$, which were located on the chromosome. As the presence of these enterotoxins is characteristic for enterotoxigenic E. coli (ETEC), they reveal an STEC/ETEC hybrid pathotype and point out the contribution of phages to the rise of new virulent bacteria. Similar results were found for the Stx2k-converting phages of these strains as they also showed considerable heterogeneity concerning insertion sites, genetic content, and structure as well as in stx expression level and cytotoxicity. The phage genome sizes ranged from 28,694 bp to 54,005 bp, with predicted CDSs between 53 and 86 .

\section{Evolutionary Viewpoints}

Although it is suggested that bacteriophages may play a major role in the development of pathogenic STEC-mediated disease, general questions on phage ecology remain unresolved. Since stx genes have never been found on plasmids or in the chromosome in nature during the last 30 years of STEC research, the question arises whether bacteria or phages benefit from the mobile stx genes or whether both of them obtain the benefit. In some studies, it has been shown that Stx production might confer protection to bacteria against predation by protozoans in its ecological niche [122], providing a plausible biological explanation for the wide distribution of stx in gut bacteria such as E. coli. Stx-producing bacteria killed Tetrahymena thermophila when grown in co-culture, and treatment with purified Stx also caused the death of protozoans [122,123]. Moreover, the bacterial SOS response system that is involved in Stx phage induction was also involved in that process. The findings of this study were in concordance with earlier observations showing that the Stx prophage enhanced the fitness of E. coli lysogens and wildtype E. coli O157:H7 strains in the presence of Tetrahymena pyriformis, and it was suggested that most of the advantages were related to Stx production [123]. Protozoa are widely distributed in nature and were present on Earth long before human beings. The fact that Stx-producing bacteria occur in many distinct ecological niches indicates that the primary role of Stx may not be causing disease in humans, but protecting the bacterial strains from predation [123]. However, it should be mentioned that similar effects on Paramecium caudatum and T. pyriformis could not be confirmed by other authors [124] and, therefore, the question of the biological function of Stx still remains open. However, to properly evaluate the effect of Stx phages on STEC survival in a bovine host, the impact of Stx on the bovine eukaryotic cells and their immunological system should also be considered, as is further discussed in Section 8.

\section{Influence of Stx Phages on the Bacterial Transcriptome}

In numerous studies, Stx prophages have been shown to influence their host strains not only by providing genes for new enzymes, toxins, etc., but also by changing their transcription patterns in many different metabolic categories, examples of which will be discussed below [44,97,125-129] (Figure 3). Early experiments were performed with microarrays containing oligonucleotides of E. coli strains EDL933 and RIMD0509952 as well as E. coli K-12 strain MG1655 [97] to discern transcriptomic changes following norfloxacin treatment. It could be shown that most of the upregulated genes were phage-related genes. Among these, the most strongly upregulated genes were the late phage genes (e.g., cro, $z 1466$ (nans-p), stx $x_{2 a}$, and $s t x_{2 b}$ ) [97].

Su et al. used a Stx lysogen in E. coli strain MG1665 $\Delta$ Min27 ( $\Delta$ stx::cat) instead of a pathogenic STEC strain for transcriptomic analysis $[127,130]$. Their data differed from 
the one obtained with the original STEC strain. They observed upregulation of transport genes such as the flagellar synthesis genes fliDESTZ and acid resistance genes (e.g., gadEW, hdeABD, and adiY) [127].

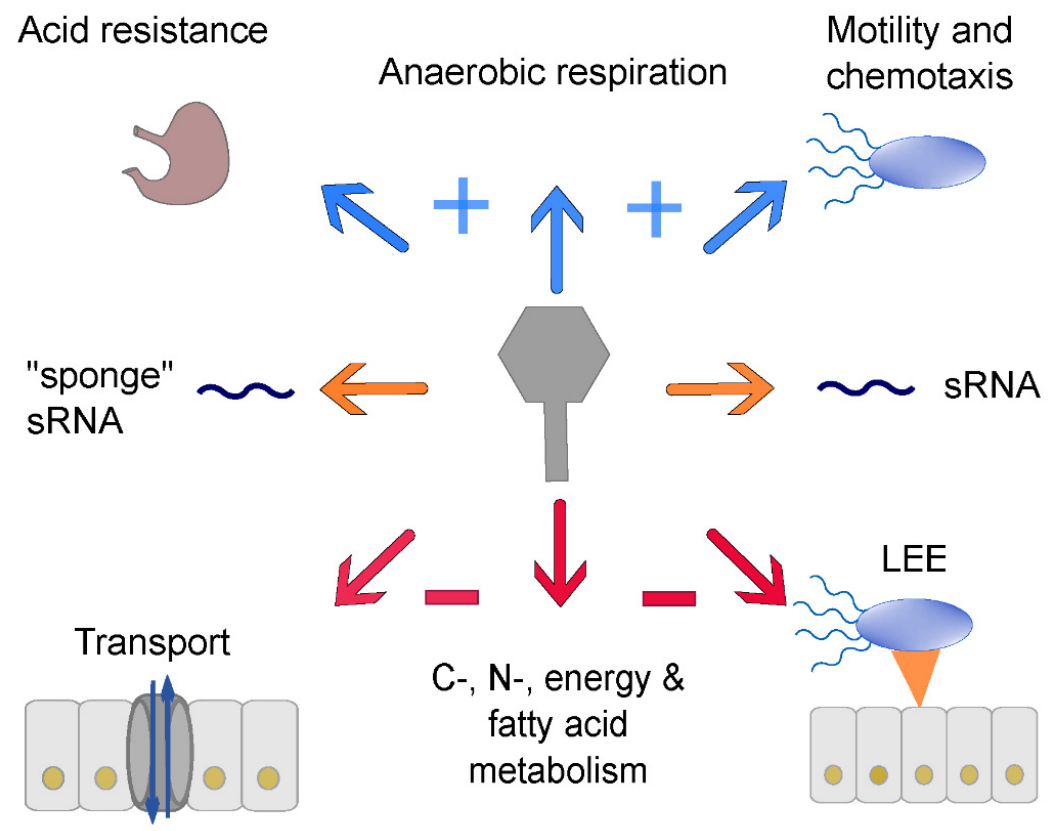

Figure 3. Influence of Stx prophages on the bacterial host transcriptome; blue arrows indicate upregulation of genes for acid resistance, anaerobic respiration, and motility and chemotaxis; orange arrows point to transcriptomic changes via sRNAs; red arrows symbolize downregulation of transport, C-, $\mathrm{N}-$, energy, and fatty acid metabolism, and LEE genes. Details are described in the text.

A typical combination of EHEC-associated virulence factors is the production of Stx and the expression of a type three secretion system (T3SS) located on the LEE [131]. The acquisition of Stx phages, especially Stx 2 phages, suppresses the expression of typical T3SS genes $[44,97,128,129]$ (Figure 3). Xu et al. showed that strains carrying a Stx2 phage showed a decrease in ler expression, which is an important regulator of the LEE locus [129]. To further investigate a possible transcription factor responsible for this transcriptomic change, cI, cII, cro, N, and Q were cloned into a Stx 2 phage lysogen of E. coli K12 and only CII showed a direct influence on T3SS expression [129]. Tozzoli et al. also identified a specific region between the gam and cII gene, which could encode one or more regulators that downregulate the T3SS, a characteristic which also points to a regulation involving cII [128].

$\mathrm{Xu}$ et al. proposed that the repression of T3SS by Stx phages provides the phage with complete control of this important colonization factor. They described a model in which expression of T3SS is controlled by the Stx phage and other effector-encoding prophages, allowing STEC to control the different regulatory elements depending on the stage of the infectious process [129].

Another study identified Cro as a regulator of T3SS during lysogeny under anaerobic conditions, and their findings were confirmed in a mouse model [95]. Cro seemed to activate 584 genes and repress 307 genes in the chromosome and, in particular, virulence factors such as fimbriae and flagella were upregulated by Cro.

The first study introducing RNA sequencing (RNA-Seq) to detect transcriptomic changes due to phage carriage showed that the E. coli strain MC1601 lysogenized with the $\varphi 24_{\mathrm{B}}$ phage exhibited stronger expression of the GAD operon including the global regulator gadE and two other gad genes (gadX and $g a d W$ ) [125] (Figure 3). These genes are responsible for the glutamate-dependent acid resistance mechanism, which is the most effective acid resistance mechanism in E. coli [132,133]. 
These data were in line with the study by Su et al. [127]. Furthermore, the role of the typical transcription factors CI, CII, and CIII was investigated, and found that CII might be involved in transcriptomic changes [125,128,129].

Veses-Garcia et al. hypothesized that there should be a differentiation between upregulated genes due to the SOS response and those due to phage regulation [125]. They observed an upregulation of DNA repair genes, iron, and phosphate acquisition and a downregulation of carbon, nitrogen, energy, and motility metabolism as well as a shift toward anaerobic respiration. Nevertheless, they found two phage-suppressed genes encoding for two pyruvate decarboxylases, which provide acetyl coenzyme A for the tricarboxylic acid cycle. These data hint at a downregulation of this metabolic pathway because acetyl coenzyme A is a key molecule [125].

Transcriptomic changes vary strongly under different environmental conditions. For example, Mitsunaka et al. observed a repression of $f l i C$ and $f l i A$ under anaerobic conditions in an E. coli K12 lysogen, which resulted in a repressed motility phenotype [134]. These results are in contrast to the study by Su et al., although it should be noted that though they both used K12 lysogens, the growth conditions differed [127]. Therefore, it is necessary to add phenotypic experiments to verify the transcriptomic data. Additionally, the heterogeneity of Stx phages may also be responsible for different transcriptomic changes [126]. Hence, the comparison of diverse studies has to be done carefully.

Berger et al. also used RNA-Seq to analyze transcriptomic changes comparing two different E. coli K12 strain MG1655 lysogens [126]. One of the lysogens carried the Stx2a phage ( $\varphi \mathrm{O} 104)$ of the hypervirulent outbreak strain E. coli O104:H4, which caused a massive disease outbreak in Germany in 2011 [135]. The closest related phage is the PA8 phage of pathogenic STEC serotype O157:H7, and it was therefore chosen as the second phage for lysogenizing the same strain [126]. The transcriptomic changes in this study were not under SOS response-inducing conditions. Upregulated genes were mainly sulfur-, motility, and chemotaxis-related. Additionally, some genes of the SOS response and several metabolic genes for mixed acid fermentation were upregulated. Most downregulated genes were involved in carbon source transport and metabolism. CI and Cro were not found to be responsible for the detected transcriptomic changes. The results of the study allowed the authors to suggest that $\varphi \mathrm{O} 104$ and $\varphi \mathrm{PA} 8$ changed the metabolism of the host significantly and that both phages might provide the host with more fitness under in vivo conditions [126].

Other studies identified prophage-encoded small regulatory RNAs (sRNA), which regulated gene expression on the chromosome, as, for example, Esr41/EcOnc 14 from the E. coli Sakai strain [44]. Waters et al. found three mRNA interaction partners for Esr41: $\operatorname{cir} A$, an iron siderophore complex uptake receptor; $b f r$, bacterioferritin; and $c h u A$, an outer membrane heme receptor. Esr41 binds in all three cases at the ribosome binding site, which suggests a translation inhibition [136].

Tree et al. investigated prophage-encoded sRNAs such as AsxR and AgvB, designated "sponge" RNA, in pathogenic STEC. They bind to the RNA-binding protein Hfq and function as "sponges" or "anti-sRNA" for the chromosomally expressed sRNAs FnrS and GcvB, respectively [44] (Figure 3).

Other studies identified prophage-encoded small regulatory RNAs (sRNA) that regulate gene expression on the chromosome. One of these is Esr41/EcOnc 14 from the EHEC Sakai strain [44]. Initially, this sRNA was hypothesized to enhance flagellin expression [137].

Another example of transcriptomic change via phage-encoded sRNAs is the IpeX sRNA encoded on the Stx-producing phage $\varphi$ PA2. The expression of IpeX reduces the expression OmpC and OmpF (outer membrane porins) [138,139]. The last example is also encoded on Stx-producing phage $\varphi 24_{\mathrm{B}}$. The function of $24 \mathrm{~b} \_1$ sRNA is elusive but might mimic eukaryotic microRNAs [140]. The deletion of this gene encoding 24B_1 leads to better prophage induction, enhanced phage production, and different bacterial cell adsorption capabilities [141]. 
It is clear that Stx phages have a remarkable impact on the host transcriptome. Most studies agree that these phages provide the host with increased acid resistance $[125,127]$ and motility $[126,127]$. On the other hand, they also seem to be responsible for repression of LEE1 [128,129] and metabolic pathways involved in energy metabolism [97,128,129], fatty acid metabolism [97,127], carbon source utilization [125,126] (Figure 3), and directly or indirectly in the tricarboxylic acid cycle (TCA) cycle [125-127]. Summing up, this also makes the Stx-encoding phage a potential metabolic burden [127]. The function of many genes in Stx-encoding phages, but also in other prophages of STEC, are still elusive [9]. Ongoing research will most probably reveal even more transcriptomic changes upon Stx phage carriage since we have only begun to understand the function of some of the genes encoded in Stx phages. This is the case for phage $\varphi 24-\mathrm{B}$, which possesses five conserved genes within the exo-xis region; ea22, orf60a, orf61, orf63, and orf73 [142-145]. ea22 and orf73 promote the maintenance of the lysogenic state, orf63 represses and delays phage induction, while orf60 and orf61 seem to promote phage induction since their deletions significantly delay the induction of the Stx $\varphi 24$ B prophage [142-146]. Moreover, adsorption of phage $\varphi 24 \mathrm{~B}$ on Escherichia coli host cells was shown to be less efficient in the absence of either orf60a or orf61 [142].

\section{Impact of Stx Phages for the Human Host (Impact on Enterocytes and Immune System)}

The environmental conditions of the human body have an effect on Stx-phage induction and consequently on the expression of Stx by the bacterial hosts [147]. At the same time, the toxin has an effect on the human (or animal) body that ranges from the cytopathic effect in different cells to interaction with blood components [148,149]. However, it is unclear what the pathogenic potential of the Stx phages is once released from the cell, particularly if they can play a role other than serving as mere vehicles for the toxin gene. It is known that phages can induce the immune system response $[150,151]$ and, as a part of this response, they can stimulate phagocytosis. One question arises then, as to whether Stx phages can directly interact with the human (or animal) cells, be phagocyted, and have an effect beyond their role in STEC pathogenicity. Bentancor et al. demonstrated that the "prokaryotic" Stx2 sequence, when introduced in eukaryotic cells, potentially allowed the expression of Stx. This expression was assessed by the activity of the toxin, by the generation of anti-Stx antibody responses, and because it caused mortality in mice [152,153]. Moreover, the lysogenization of the laboratory strain E. coli C600 by Stx phage 933W was sufficient to cause renal and intestinal damage in a mouse model in the absence of other STEC pathogenicity factors [154]. This damage could be caused by bacterial Stx expression in the absence of other adhesion or invasion factors, by the transduction of Stx phages to other bacterial hosts in the gut or, considering previous studies, by direct interactions of free Stx phage virions with the eukaryotic cells. Although this last option was not confirmed, free $933 \mathrm{~W}$ phages were detected in the brain tissue of mice, in the same areas where Stx activity, astrocyte activity, and neuronal damage were detected [154]. Phages can translocate more effectively than bacteria along the human tissues [150,155], and they are abundantly found in different human samples such as ascitic fluid, blood/serum, urine, or cerebrospinal fluid [156].

Regardless of the role of Stx phages, the expression of Stx may modulate the innate immune response of human enterocytes. STEC(EHEC)-derived Stx inhibits NF- $\mathrm{BB}$ signaling and chemokine gene expression in T84 cells [157]. Moreover, observations indicate that strains expressing Stx1 and Stx2 produced fewer chemokines than the isolates only harboring one type (stx2) [158].

Stx also favors the attachment of the bacteria to the colonic epithelium. Enhanced colonization of O157:H7 expressing Stx has also been demonstrated and attributed to an Stx-mediated increase of nucleolin, an eukaryotic receptor recognized by the intimin, responsible for the intimate adhesion of the pathogen to the enterocyte surface [159]. However, these observations were attributable to the toxin expression and there is no 
direct evidence of the role of Stx phages on adherence other than the modulated level of Stx expression [159].

When observing the impact of Stx phages in animal hosts, it has been observed that Stx1 markedly induced apoptosis in a stimulated B lymphoma bovine cell line, while hindered the proliferation of bovine lymphocytes by blocking their activation and, consequently, causing suppression of the mucosa-associated immune response against STEC infection [160]. Again, the effect was attributed to the Stx1 activity, and not to the phages themselves.

Stx2, particularly Stx2a and Stx2c subtypes, affect regeneration of the gastrointestinal epithelium in calves. Higher STEC transmission and excretion levels from the animals colonized by strains expressing the Stx2a subtype has been shown since Stx2a enhances E. coli $\mathrm{O} 157$ colonization of calves by restricting regeneration and turnover of the colonized epithelium [119]. Here, the role of Stx phages was confirmed, as a faster induction of gene expression from the Stx2a-encoding prophage compared to that from the Stx2c-encoding prophage can account for the more evident effect of this toxin subtype. In contrast, this same study did not show evidence to support a role of Stx2a in immune suppression [119].

\section{Structure and Function of Non-Stx Phages of Pathogenic STEC}

Aside from Stx phages, other non-Stx prophages are found in the genome of STEC, some of them including complete and inducible phages, but also non-inducible, remnant, cryptic, or residual phages. Polylysogeny is therefore a very common occurrence in STEC strains, and a good example is O157 strain Sakai, which carries up to 18 different prophages [13]. As temperate phages, prophages preferentially belong to the Siphoviridae or Podoviridae morphological types [161] and usually display a modular structure, the so-called genetic mosaicism [162]. Similar sequences are also shared by different phages. For this reason, it is difficult to distinguish between Stx and non-Stx phages in the STEC complete genomes because these similar sequences confound the software used for contigs assembly, producing false chimeras. This problem is overcome when using sequencing platforms that generate longer reads [47], or by inducing and isolating the prophages before sequencing [10].

Nevertheless, the abundance of prophages in STEC strains suggests some advantage for the actors implicated, that is, bacteria and phages. Bacteria seem to keep all this prophage pool to incorporate new genetic traits [163], but also to enhance the mobilization of their genome $[13,164]$ or, as mentioned in the previous section, confer fitness and improve growth, or regulate other elements.

Prophages coexisting in a bacterial genome also take advantage of polylysogeny, increasing their genetic diversity. Multiple recombination events between prophages located in the same genome might occur [16,163], mainly between the identical fragments of DNA shared by the co-existing prophages. These shared sequences serve to anchor the activity of recombinases, which in many cases are encoded by the prophage genomes themselves [165] or that can be provided by the host. For example, new Stx1 phages are generated after recombination events occurring between the Stx1 and Stx2 prophages [13].

Other genetic elements can interact with prophages, for example, by taking their capsids to mobilize themselves; in E. coli, this fact has been described for genomic islands [166], defective prophages $[14,167,168]$, and plasmids [169].

\section{Interaction between Stx and Non-Stx Phages}

Stx phages are the most studied phages because of their implication in STEC pathogenicity, but there are other prophages related with STEC virulence such as the temperate phages encoding different types of toxins or phages encoding effector proteins (Table 1). 
Table 1. Virulence factors other than stx and antibiotic resistance genes (ARG) encoded in the genome of E. coli phages.

\begin{tabular}{|c|c|c|c|c|c|}
\hline Source of Phage & Virulence Factor or ARG & E. coli Strain * & Phage & Phage Replication & Reference \\
\hline $\begin{array}{l}\text { Induced from } \\
\text { bacteria }\end{array}$ & Toxin: Cytolethal distending toxin I & $\begin{array}{l}\text { Enteropathogenic } E \text {. } \\
\quad \text { coli O127:H7 }\end{array}$ & $\mathrm{CDT}-1 \varphi$ & Temperate & [170] \\
\hline $\begin{array}{l}\text { Induced from } \\
\text { bacteria }\end{array}$ & Toxin: Cytolethal distending toxin V & $\begin{array}{l}\text { Enterohemorrhagic } E \text {. } \\
\text { coli O157:H7 } \\
\text { Environmental E. coli } \\
\quad \text { O22:H8 }\end{array}$ & $\begin{array}{l}\varphi 125 \\
\varphi 62\end{array}$ & Temperate & [171] \\
\hline $\begin{array}{l}\text { Sequenced from } \\
\text { bacteria }\end{array}$ & Toxin: Cytolethal distending toxin V & $\begin{array}{l}\text { Enterohemorrhagic } E \text {. } \\
\quad \text { coli O157:H43 }\end{array}$ & P2-like & $\begin{array}{l}\text { Non-inducible, } \\
\text { temperate }\end{array}$ & [172] \\
\hline $\begin{array}{c}\text { Induced from } \\
\text { bacteria }\end{array}$ & Adhesion: Lom & Diverse E. coli strains & $\begin{array}{l}\text { Various lambdoid } \\
\text { phages }\end{array}$ & Temperate & [173] \\
\hline $\begin{array}{c}\text { Induced from } \\
\text { bacteria }\end{array}$ & $\underline{\text { Serum resistance: }}$ Bor & Diverse E. coli strains & $\begin{array}{l}\text { Various lambdoid } \\
\text { phages }\end{array}$ & Temperate & [173] \\
\hline $\begin{array}{l}\text { Induced from } \\
\text { bacteria }\end{array}$ & $\frac{\text { Immunoglobulin binding protein: }}{\text { EibD }}$ & $\begin{array}{l}\text { E. coli reference strain } \\
\text { ECOR-9 }\end{array}$ & & Temperate & [174] \\
\hline $\begin{array}{l}\text { Induced from } \\
\text { bacteria }\end{array}$ & T3SS effector protein: Cif & $\begin{array}{l}\text { Enteropathogenic } E \\
\quad \text { coli } \mathrm{O} 103: \mathrm{H} 2\end{array}$ & Cif-encoding phage & Temperate & [175] \\
\hline $\begin{array}{l}\text { Sequenced from } \\
\text { bacteria }\end{array}$ & T3SS effector protein: EspF (TccP) & $\begin{array}{l}\text { Enterohemorrhagic } E \text {. } \\
\text { coli O157:H7 Sakai }\end{array}$ & CP-933U & Cryptic prophage & [176] \\
\hline $\begin{array}{l}\text { Sequenced from } \\
\text { bacteria }\end{array}$ & T3SS effector protein: EspJ & $\begin{array}{l}\text { Enterohemorrhagic } E . \\
\text { coli O157:H7 Sakai }\end{array}$ & CP-933U & Cryptic prophage & [176] \\
\hline $\begin{array}{l}\text { Sequenced from } \\
\text { bacteria }\end{array}$ & T3SS effector protein: EspL2 & $\begin{array}{l}\text { Enterohemorrhagic } E \text {. } \\
\text { coli O157:H7 Sakai }\end{array}$ & $\begin{array}{l}\text { SpLE3 phage-like } \\
\text { element }\end{array}$ & Unknown & [177] \\
\hline $\begin{array}{l}\text { Induced from } \\
\text { bacteria }\end{array}$ & T3SS effector protein: NleA & $\begin{array}{l}\text { Attaching-effacing } E . \\
\text { coli } \mathrm{O} 84: \mathrm{H} 4\end{array}$ & Stx1 phage & Temperate & [51] \\
\hline $\begin{array}{l}\text { Induced from } \\
\text { bacteria }\end{array}$ & $\begin{array}{l}\text { T3SS effector protein: NleB, NleC, } \\
\text { NleH, NleG espJ, and nleA/espI }\end{array}$ & $\begin{array}{l}\text { Enteropathogenic } E \text {. } \\
\text { coli } \\
\text { Enterohemorrhagic } E . \\
\text { coli }\end{array}$ & Cif-encoding phage & Temperate & [175] \\
\hline $\begin{array}{l}\text { Sequenced from } \\
\text { bacteria }\end{array}$ & T3SS effector protein: NleC & $\begin{array}{l}\text { Enterohemorrhagic } E \text {. } \\
\quad \text { coli O157:H7 }\end{array}$ & СР-933K & Cryptic prophage & [178] \\
\hline $\begin{array}{l}\text { Sequenced from } \\
\text { bacteria }\end{array}$ & T3SS effector protein: NleD & $\begin{array}{l}\text { Enterohemorrhagic } E \text {. } \\
\quad \text { coli O157:H7 }\end{array}$ & CP-933K & Cryptic prophage & [178] \\
\hline $\begin{array}{l}\text { Induced from } \\
\text { bacteria }\end{array}$ & T3SS effector protein: $\mathrm{NleH}$ & $\begin{array}{l}\text { Enteropathogenic } E \text {. } \\
\quad \text { coli O127:H7 }\end{array}$ & & Temperate & [170] \\
\hline $\begin{array}{l}\text { Induced from } \\
\text { bacteria }\end{array}$ & $\begin{array}{l}\text { Metabolism: NanS-p, } \\
\text { O-acetyl esterase for the use of } \\
\text { sialic acids }\end{array}$ & $\begin{array}{l}\text { Enterohemorrhagic } E \text {. } \\
\quad \text { coli O157:H7 }\end{array}$ & Various phages & Temperate & [102] \\
\hline $\begin{array}{l}\text { Sequenced from } \\
\text { bacteria }\end{array}$ & $\begin{array}{c}\text { ARG: aadA1, aadA2, aadA22, aac(3)-Via } \\
\text { and } A P H(4)-I a b l a \\
\text { TEM, } c m l A 1, d r f A, \\
\text { mefB sul1, sul3, and tet(C) }\end{array}$ & $\begin{array}{l}\text { Enterotoxigenic } E . \\
\quad \text { coli (ETEC) }\end{array}$ & Various phages & Temperate & [179] \\
\hline $\begin{array}{l}\text { Isolated from } \\
\text { vegetables }\end{array}$ & $\begin{array}{c}\text { ARG: } b l a_{\mathrm{CTX}-\mathrm{M} 1}, b l a_{\mathrm{CTX}-\mathrm{M} 9}, b l a_{\mathrm{VIM}} \\
\quad m e c A, \text { arm } A, q n r A, \text { sul1 }\end{array}$ & $\begin{array}{l}\text { Replicative on } \\
\text { non-pathogenic } E \text {. } \\
\text { coli WG5 strain }\end{array}$ & Phage pool & Unknown & [180] \\
\hline Isolated from soil & $\begin{array}{c}\text { ARG: } b l a_{\mathrm{TEM}}, b l a_{\mathrm{CTX}-\mathrm{M} 1}, b l a_{\mathrm{CTX}} \mathrm{M} 9, \\
\operatorname{armA}, q n A, q n r S, \text { sul1 }\end{array}$ & $\begin{array}{l}\text { Replicative on } \\
\text { non-pathogenic } E \text {. } \\
\text { coli WG5 strain }\end{array}$ & Phage pool & Unknown & [180] \\
\hline Isolated from meat & $\begin{array}{c}\text { ARG: } b l a_{\mathrm{TEM}}, b l a_{\mathrm{CTX}-\mathrm{M} 1}, b l a_{\mathrm{CTX}-\mathrm{M} 9}, \\
\text { bla }_{\mathrm{OXA}-48}, \text { bla } \\
\text { qnrS, sul1 }\end{array}$ & $\begin{array}{l}\text { Replicative on } \\
\text { non-pathogenic } E \text {. } \\
\text { coli WG5 strain }\end{array}$ & Phage pool & Unknown & [181] \\
\hline $\begin{array}{l}\text { Isolated from } \\
\text { chicken meat }\end{array}$ & ARG: aphA1, bla $a_{\mathrm{TEM}}$ floR, tet $A$ & $\begin{array}{c}\text { Replicative on } \\
\text { non-pathogenic } E . \\
\text { coli DSM } 12242 \text { strain }\end{array}$ & Various phages & Virulent & [182] \\
\hline Isolated from fish & $\begin{array}{c}\text { ARG: } b l a_{\mathrm{TEM}}, \text { bla }_{\mathrm{CTX}-\mathrm{M} 1}, \text { bla }_{\mathrm{CTX}-\mathrm{M} 9,} \\
\text { bla }_{\mathrm{OXA}-48}, \text { bla }_{\mathrm{VIM}}, \text { arm } A, \text { qnr } A \\
\text { tet } \mathrm{W}, \text { sul1 }\end{array}$ & $\begin{array}{l}\text { Replicative on } \\
\text { non-pathogenic } E \text {. } \\
\text { Coli WG5 strain }\end{array}$ & Phage pool & Unknown & [183] \\
\hline
\end{tabular}


Table 1. Cont.

\begin{tabular}{|c|c|c|c|c|c|}
\hline Source of Phage & Virulence Factor or ARG & E. coli Strain * & Phage & Phage Replication & Reference \\
\hline $\begin{array}{l}\text { Isolated from } \\
\text { dog urine }\end{array}$ & ARG: $b l a_{\mathrm{TEM}}$, sulI, sulII, or strA & $\begin{array}{c}\text { Replicative on } \\
\text { non-pathogenic } E \text {. } \\
\text { coli DSM } 12242 \text { strain }\end{array}$ & Various phages & Virulent & [184] \\
\hline $\begin{array}{c}\text { Isolated from } \\
\text { surfaces of equine } \\
\text { veterinary clinics }\end{array}$ & ARG: addA1, cmlA & $\begin{array}{c}\text { Replicative on } \\
\text { non-pathogenic } E \text {. } \\
\text { coli DSM } 12242 \text { strain }\end{array}$ & Various phages & Virulent & [185] \\
\hline $\begin{array}{l}\text { Isolated from } \\
\text { wastewater }\end{array}$ & $\begin{array}{l}\text { ARG: Fragments of bla }{ }_{\mathrm{TEM}}, \mathrm{cmlA}, \mathrm{qnrS} \text {, } \\
\text { tetM, mer-1 sul } 3 \text {, and sul4) }\end{array}$ & $\begin{array}{l}\text { Replicative on } \\
\text { various } \\
\text { multidrug-resistant } \\
\text { E. coli hosts }\end{array}$ & $\begin{array}{l}\text { Two T7-Like } \\
\text { phages }\end{array}$ & Virulent & [186] \\
\hline $\begin{array}{l}\text { Isolated from soil } \\
\text { and water }\end{array}$ & $\underline{\text { ARG: }}$ bla $a_{C T X-M}$ & $\begin{array}{c}\text { Replicative on } \\
\text { bla } a_{C T X-M-\text { negative }} \\
\text { environmental } \\
\text { E. coli isolates }\end{array}$ & $\begin{array}{l}\text { Seven T4-Like } \\
\text { phages }\end{array}$ & Virulent & [187] \\
\hline $\begin{array}{l}\text { Induced from } \\
\text { bacteria }\end{array}$ & ARG: $b l a_{S H V-2}$ & $\begin{array}{l}\text { Clinical E. coli } \\
\quad \text { O8:H19 }\end{array}$ & $\begin{array}{l}\text { P1-like phage } \\
\text { RCS47 }\end{array}$ & $\begin{array}{l}\text { Temperate } \\
\text { plasmid-like }\end{array}$ & [188] \\
\hline
\end{tabular}

* Definitions of pathogenic E. coli are according to Nataro and Kaper [131]; ARG: antibiotic resistance genes; T3SS: type III secretion system.

Not only temperate phages contribute to the repertoire of weapons used by STEC. Virulent phages, which mostly conduct generalized transduction, might provide STEC with antibiotic resistance. While specialized transduction is the canonical mechanism for incorporating genes through temperate phages that harbor a single and specific gene in a precise location of their genome, generalized transduction is understood as the mechanism that mobilizes any fragment of the bacterial genome [189]. The bacterial DNA is cleaved at a specific sequence (pac-like site), which is similar to the pac site located in the phage DNA from which phages start filling their capsids. This "mistake" leads to phage capsids full of bacterial DNA instead of phage DNA. Generalized transducing particles are not competent phages since they cannot propagate, but they can transfer any fragment of bacterial DNA including genes of interest involved in the bacterial pathogenicity such as antibiotic resistance genes (ARGs) [190]. E. coli species including pathogenic E. coli use their arsenal of prophages to mobilize specific genes by specialized transduction, but they could also mobilize other DNA fragments including ARGs [191]. The origin of ARG-transducing phage particles is thought to be the bacterial strains, but they can also be found as free particles in different environments [181,192] (Table 1).

Although generalized transducing particles are a likely source of ARGs detected in phage particles, there are some studies in which ARGs have been detected in phage particles able to propagate in a host strain, for instance, in E. coli K-12 derivatives (Table 1). Since generalized transducing phages should not be able to infect and propagate using a host strain, it is assumed that other phage particles, virulent, or temperate are responsible for the new progeny of phages encoding the ARG. Although the nature of the ARG-encoding phage particles detected is not known, it is assumed that both specialized and generalized phage particles contribute to the transmission of ARGs originated in the chromosome or the plasmids of the host strains, and that all contribute to the pool of phages that can be detected in numerous environments.

The third newly described transduction mechanism, the lateral transduction [193], involves prophages that, by delaying the excision from the bacterial chromosome, can package enormous amounts of bacterial DNA. This mechanism provides a better explanation than the generalized transduction for the high amounts of ARG-carrying phage particles observed after induction of clinical E. coli strains $[191,194]$. Although it was initially described in Staphylococcus, it is reasonable to believe that similar or the same mechanism will be reported soon in E. coli.

In addition to non-Stx phages carrying genes directly related to virulence that are incorporated in STEC by transduction, the presence of other non-Stx prophages have a direct influence on the STEC pangenome and its pathogenicity. As above-mentioned, 
$\mathrm{Xu}$ et al. proposed a model in which expression of T3SS is controlled by the Stx phage, but also by non-Stx phages encoding T3 effector molecules [129], or Lom or Bor genes in prophages confer serum resistance and enhance adhesion (Table 1).

Prophages present in an STEC genome are used as protection against superinfection by other phages. Non-lysogens are vulnerable to phage infection and lysis while the lysogens are immune to superinfection with certain phages. For instance, E. coli prophage Qin, also found in STEC, is a cryptic prophage that encodes a small protein, DicB, which protects the lysogens from future phage infections [195].

Several physiological functions such as stress tolerance, biofilm formation, antibiotic resistance, and other advantages to the host genome are attributed to prophages in E. coli (Wang et al. 2010) [196]. For example prophage e14, present in different E. coli strains, encodes important functional genes such as lit (phage T4 exclusion), mcrA (modified cytosine restriction activity), and pin (recombinase) [197]. A study conducted by deleting nine non-Stx cryptic prophages (CP4-6, DLP12, e14, rac, Qin, CP4-44, CPS-53, CPZ-55, and $\mathrm{CP} 4-57$ ) from the E. coli genome concluded that different prophages protected the lysogen against different antibiotics against other environmental stresses such as acid, heat, osmotic and oxidative stresses, and increased biofilm formation, essentially by inhibiting cell division [196].

Although not related to the STEC-typical mechanisms of pathogenicity, induction of E. coli prophages suggested an indirect role of the bacterial phages in the modulation of human host immunity and in a particular case, this was associated with the development of type 1 diabetes [198]. Induction of E. coli prophages causes depletion of the population of amyloid-producing E. coli. Many pathogenic E. coli produce curli, which are a type of naturally-occurring amyloid fibers. Depletion of E. coli populations producing curli has been associated with seroconversion, a period during which autoantibodies to antigens of pancreatic $\beta$-cells or insulin are produced, finally leading to the development of diabetes type 1 in children [198].

In contrast, certain prophages are inserted into transcriptional factor $m \operatorname{lr} A$ (yehV), a regulator responsible for curli generation and biofilm formation, therefore in situations in which prophages are inserted, curli and biofilm production in some E. coli O157:H7 isolates are abolished, reducing bacterial pathogenesis [199].

\section{Conclusions}

Many years of phage research in the field of pathogenic STEC have shed light onto diverse genetic features of their lambdoid phages and have helped to better understand the manifold functions hidden behind these heterogeneous particles. Nevertheless, a series of questions remain unresolved and, therefore, Stx phage research represents an important tool to better elucidate the distribution of phages in their hosts, their contribution to the bacterial metabolism, and finally, to the development of human disease. This knowledge will only be possible with approaches that include strong interaction among different scientific disciplines (e.g., medicine, microbiology, genetics, biochemistry, biophysics, bioinformatics, and biotechnology).

Author Contributions: Conceptualization, L.R.-R., M.S., N.H., H.S., and M.M.; Writing-Original draft preparation, L.R.-R., M.S., N.H., H.S., and M.M.; Writing-Review and editing L.R.-R., M.S., N.H., H.S., and M.M.; Visualization, L.R.-R., M.S., N.H., H.S., and M.M. All authors have read and agreed to the published version of the manuscript.

Funding: This research was funded by the Spanish Ministerio de Innovación y Ciencia (grant number AGL2016-75536-P), the Agencia Estatal de Investigación (AEI), the European regional fund (ERF), and the Generalitat de Catalunya (grant number 2017SGR170).

Institutional Review Board Statement: Not applicable.

Informed Consent Statement: Not applicable. 
Acknowledgments: L.R.-R. is a Serra Húnter Fellow.

Conflicts of Interest: The authors declare no conflict of interest.

\section{References}

1. Scotland, S.M.; Smith, H.R.; Willshaw, G.A.; Rowe, B. Vero cytotoxin production in strain of Escherichia coli is determined by genes carried on bacteriophage. Lancet 1983, 322, 216. [CrossRef]

2. O'Brien, A.D.; Newland, J.W.; Miller, S.F.; Holmes, R.K.; Smith, H.W.; Formal, S.B. Shiga-like toxin-converting phages from Escherichia coli strains that cause hemorrhagic colitis or infantile diarrhea. Science 1984, 226, 694-696. [CrossRef]

3. Huang, A.; Friesen, J.; Brunton, J.L. Characterization of a bacteriophage that carries the genes for production of Shiga-like toxin 1 in Escherichia coli. J. Bacteriol. 1987, 169, 4308-4312. [CrossRef] [PubMed]

4. Datz, M.; Janetzki-Mittmann, C.; Franke, S.; Gunzer, F.; Schmidt, H.; Karch, H. Analysis of the enterohemorrhagic Escherichia coli O157 DNA region containing lambdoid phage gene $p$ and shiga-like toxin structural genes. Appl. Environ. Microbiol. 1996, 62, 791-797. [CrossRef] [PubMed]

5. Friedman, D.I.; Court, D.L. Bacteriophage lambda: Alive and well and still doing its thing. Curr. Opin. Microbiol. $2001,4,201-207$. [CrossRef]

6. Johansen, B.K.; Wasteson, Y.; Granum, P.E.; Brynestad, S. Mosaic structure of Shiga-toxin-2-encoding phages isolated from Escherichia coli O157:H7 indicates frequent gene exchange between lambdoid phage genomes. Microbiology 2001, 147, 1929-1936. [CrossRef] [PubMed]

7. Karch, H.; Schmidt, H.; Janetzki-Mittmann, C.; Scheef, J.; Kroger, M. Shiga toxins even when different are encoded at identical positions in the genomes of related temperate bacteriophages. Mol. Gen. Genet. 1999, 262, 600-607. [CrossRef]

8. Neely, M.N.; Friedman, D.I. Functional and genetic analysis of regulatory regions of coliphage H- 19B: Location of shiga-like toxin and lysis genes suggest a role for phage functions in toxin release. Mol. Microbiol. 1998, 28, 1255-1267. [CrossRef]

9. Smith, D.L.; Rooks, D.J.; Fogg, P.C.; Darby, A.C.; Thomson, N.R.; McCarthy, A.J.; Allison, H.E. Comparative genomics of Shiga toxin encoding bacteriophages. BMC Genom. 2012, 13, 311. [CrossRef]

10. Zuppi, M.; Tozzoli, R.; Chiani, P.; Quiros, P.; Martinez-Velazquez, A.; Michelacci, V.; Muniesa, M.; Morabito, S. Investigation on the evolution of Shiga toxin-converting phages based on whole genome sequencing. Front. Microbiol. 2020, 11. [CrossRef]

11. Campbell, A. Comparative molecular biology of lambdoid phages. Annu. Rev. Microbiol. 1994, 48, 193-222. [CrossRef]

12. Casjens, S.R.; Hendrix, R.W. Bacteriophage lambda: Early pioneer and still relevant. Virology 2015, 479-480, 310-330. [CrossRef]

13. Asadulghani, M.; Ogura, Y.; Ooka, T.; Itoh, T.; Sawaguchi, A.; Iguchi, A.; Nakayama, K.; Hayashi, T. The defective prophage pool of Escherichia coli O157: Prophage-prophage interactions potentiate horizontal transfer of virulence determinants. PLoS Pathog. 2009, 5, 1000408. [CrossRef]

14. García-Aljaro, C.; Ballesté, E.; Muniesa, M. Beyond the canonical strategies of horizontal gene transfer in prokaryotes. Curr. Opin. Microbiol. 2017, 38, 95-105. [CrossRef]

15. Muniesa, M.; Schmidt, H. Shiga toxin-encoding phages: Multifunctional gene ferries. Pathog. Escherichia coli Mol. Cell Mikrobiol. 2014, 57-77. [CrossRef]

16. Ogura, Y.; Ooka, T.; Iguchi, A.; Toh, H.; Asadulghani, M.; Oshima, K.; Kodama, T.; Abe, H.; Nakayama, K.; Kurokawa, K.; et al. Comparative genomics reveal the mechanism of the parallel evolution of $\mathrm{O} 157$ and non-O157 enterohemorrhagic Escherichia coli. Proc. Natl. Acad. Sci. USA 2009, 106, 17939-17944. [CrossRef] [PubMed]

17. Ohnishi, M.; Terajima, J.; Kurokawa, K.; Nakayama, K.; Murata, T.; Tamura, K.; Ogura, Y.; Watanabe, H.; Hayashi, T. Genomic diversity of enterohemorrhagic Escherichia coli 0157 revealed by whole genome PCR scanning. Proc. Natl. Acad. Sci. USA 2002, 99, 17043-17048. [CrossRef]

18. Plunkett, G.; Rose, D.J.; Durfee, T.J.; Blattner, F.R. Sequence of Shiga toxin 2 phage 933W from Escherichia coli O157:H7: Shiga toxin as a phage late-gene product? J. Bacteriol. 1999, 181, 1767-1778. [CrossRef] [PubMed]

19. Schmidt, H. Shiga-toxin-converting bacteriophages. Res. Microbiol. 2001, 152, 687-695. [CrossRef]

20. Krüger, A.; Lucchesi, P.M.A. Shiga toxins and stx phages: Highly diverse entities. Microbiology 2015, 161, 1-12. [CrossRef] [PubMed]

21. Yang, X.; Bai, X.; Zhang, J.; Sun, H.; Fu, S.; Fan, R.; He, X.; Scheutz, F.; Matussek, A.; Xiong, Y. Escherichia coli strains producing a novel Shiga toxin 2 subtype circulate in China. Int. J. Med. Microbiol. 2020, 310. [CrossRef] [PubMed]

22. Yara, D.A.; Greig, D.R.; Gally, D.L.; Dallman, T.J.; Jenkins, C. Comparison of Shiga toxin-encoding bacteriophages in highly pathogenic strains of shiga toxin-producing Escherichia coli O157:H7 in the UK. Microb. Genom. 2020, 6. [CrossRef] [PubMed]

23. Smith, D.L.; James, C.E.; Sergeant, M.J.; Yaxian, Y.; Saunders, J.R.; McCarthy, A.J.; Allison, H.E. Short-tailed Stx phages exploit the conserved YaeT protein to disseminate Shiga toxin genes among enterobacteria. J. Bacteriol. 2007, 189, 7223-7233. [CrossRef]

24. Muniesa, M.; Blanco, J.E.; de Simón, M.; Serra-Moreno, R.; Blanch, A.R.; Jofre, J. Diversity of st $x 2$ converting bacteriophages induced from Shiga-toxin-producing Escherichia coli strains isolated from cattle. Microbiology 2004, 150, 2959-2971. [CrossRef]

25. Rooks, D.J.; Libberton, B.; Woodward, M.J.; Allison, H.E.; McCarthy, A.J. Development and application of a method for the purification of free shigatoxigenic bacteriophage from environmental samples. J. Microbiol. Methods 2012, 91, 240-245. [CrossRef]

26. Smith, D.L.; Wareing, B.M.; Fogg, P.C.M.; Riley, L.M.; Spencer, M.; Cox, M.J.; Saunders, J.R.; McCarthy, A.J.; Allison, H.E. Multilocus characterization scheme for shiga toxin-encoding bacteriophages. Appl. Environ. Microbiol. 2007, 73, 8032-8040. [CrossRef] [PubMed] 
27. Islam, M.R.; Ogura, Y.; Asadulghani, M.; Ooka, T.; Murase, K.; Gotoh, Y.; Hayashi, T. A sensitive and simple plaque formation method for the Stx2 phage of Escherichia coli O157: H7, which does not form plaques in the standard plating procedure. Plasmid 2012, 67, 227-235. [CrossRef] [PubMed]

28. Watarai, M.; Sato, T.; Kobayashi, M.; Shimizu, T.; Yamasaki, S.; Tobe, T.; Sasakawa, C.; Takeda, Y. Identification and characterization of a newly isolated Shiga toxin 2-converting phage from Shiga toxin-producing Escherichia coli. Jpn. J. Infect. Dis. 1999, 52, 27. [CrossRef]

29. Herold, S.; Karch, H.; Schmidt, H. Shiga toxin-encoding bacteriophages-genomes in motion. Int. J. Med. Microbiol. 2004, 294, 115-121. [CrossRef]

30. Wagner, P.L.; Waldor, M.K. Minireview bacteriophage control of bacterial virulence. Society 2002, 70, 3985-3993. [CrossRef]

31. Neely, M.N.; Friedman, D.I. Arrangement and functional identification of genes in the regulatory region of lambdoid phage H-19B, a carrier of a Shiga-like toxin. Gene 1998, 223, 105-113. [CrossRef]

32. Recktenwald, J.; Schmidt, H. The nucleotide sequence of Shiga toxin (Stx) 2e-encoding phage $\varphi \mathrm{P} 27$ is not related to other Stx phage genomes, but the modular genetic structure is conserved. Infect. Immun. 2002, 70, 1896-1908. [CrossRef] [PubMed]

33. Wagner, P.L.; Neely, M.N.; Zhang, X.; Acheson, D.W.K.; Waldor, M.K.; Friedman, D.I. Role for a phage promoter in Shiga toxin 2 expression from a pathogenic Escherichia coli strain. J. Bacteriol. 2001, 183, 2081-2085. [CrossRef] [PubMed]

34. Zhang, L.X.; Simpson, D.J.; McMullen, L.M.; Gänzle, M.G. Comparative genomics and characterization of the late promoter $p R^{\prime}$ from shiga toxin prophages in Escherichia coli. Viruses 2018, 10, 595. [CrossRef]

35. LeJeune, J.T.; Abedon, S.T.; Takemura, K.; Christie, N.P.; Sreevatsan, S. Human Escherichia coli O157:H7 genetic marker in isolates of bovine origin. Emerg. Infect. Dis. 2004, 10, 1482-1485. [CrossRef]

36. Matsumoto, M.; Suzuki, M.; Takahashi, M.; Hirose, K.; Minagawa, H.; Ohta, M. Identification and epidemiological description of enterohemorrhagic Escherichia coli O157 strains producing low amounts of Shiga toxin 2 in Aichi Prefecture, Japan. Jpn. J. Infect. Dis. 2008, 61, 442-445. [PubMed]

37. Koitabashi, T.; Vuddhakul, V.; Radu, S.; Morigaki, T.; Asai, N.; Nakaguchi, Y.; Nishibuchi, M. Genetic characterization of Escherichia coli O157:H7/- strains carrying the stx2 gene but not producing shiga toxin 2. Microbiol. Immunol. 2006, 50, 135-148. [CrossRef]

38. Olavesen, K.K.; Lindstedt, B.A.; Løbersli, I.; Brandal, L.T. Expression of Shiga toxin 2 (Stx2) in highly virulent Stx-producing Escherichia coli (STEC) carrying different anti-terminator ( $q$ ) genes. Microb. Pathog. 2016, 97, 1-8. [CrossRef] [PubMed]

39. Tyler, J.S.; Mills, M.J.; Friedman, D.I. The operator and early promoter region of the Shiga toxin type 2-encoding bacteriophage 933W and control of toxin expression. J. Bacteriol. 2004, 186, 7670-7679. [CrossRef] [PubMed]

40. Shi, T.; Friedman, D.I. The operator-early promoter regions of Shiga-toxin bearing phage H-19B. Mol. Microbiol. 2001, 41, 585-599. [CrossRef]

41. Livny, J.; Friedman, D.I. Characterizing spontaneous induction of Stx encoding phages using a selectable reporter system. Mol. Microbiol. 2004, 51, 1691-1704. [CrossRef]

42. Waldor, M.K.; Friedman, D.I. Phage regulatory circuits and virulence gene expression. Curr. Opin. Microbiol. 2005, 8, 459-465. [CrossRef]

43. Riley, L.M.; Veses-Garcia, M.; Hillman, J.D.; Handfield, M.; McCarthy, A.J.; Allison, H.E. Identification of genes expressed in cultures of E. coli lysogens carrying the Shiga toxin-encoding prophage $\psi 24$ B. BMC Microbiol. 2012, 12, 42. [CrossRef] [PubMed]

44. Tree, J.J.; Granneman, S.; McAteer, S.P.; Tollervey, D.; Gally, D.L. Identification of bacteriophage-encoded anti-sRNAs in pathogenic Escherichia coli. Mol. Cell 2014, 55, 199-213. [CrossRef] [PubMed]

45. Sy, B.M.; Lan, R.; Tree, J.J. Early termination of the Shiga toxin transcript generates a regulatory small RNA. Proc. Natl. Acad. Sci. USA 2020, 117, 25055-25065. [CrossRef] [PubMed]

46. Hendrix, R.W.; Lawrence, J.G.; Hatfull, G.F.; Casjens, S. The origins and ongoing evolution of viruses. Trends Microbiol. 2000, 8, 504-508. [CrossRef]

47. Shaaban, S.; Cowley, L.A.; McAteer, S.P.; Jenkins, C.; Dallman, T.J.; Bono, J.L.; Gally, D.L. Evolution of a zoonotic pathogen: Investigating prophage diversity in enterohaemorrhagic Escherichia coli O157 by long-read sequencing. Microb. Genom. 2016, 2, e000096. [CrossRef] [PubMed]

48. Serra-Moreno, R.; Jofre, J.; Muniesa, M. The CI repressors of Shiga toxin-converting prophages are involved in coinfection of Escherichia coli strains, which causes a down regulation in the production of Shiga toxin 2. J. Bacteriol. 2008, 190, 4722-4735. [CrossRef]

49. Fogg, P.C.M.; Rigden, D.J.; Saunders, J.R.; McCarthy, A.J.; Allison, H.E. Characterization of the relationship between integrase, excisionase and antirepressor activities associated with a superinfecting Shiga toxin encoding bacteriophage. Nucleic Acids Res. 2011, 39, 2116-2129. [CrossRef]

50. Serra-Moreno, R.; Jofre, J.; Muniesa, M. Insertion site occupancy by st $x_{2}$ bacteriophages depends on the locus availability of the host strain chromosome. J. Bacteriol. 2007, 189, 6645-6654. [CrossRef]

51. Creuzburg, K.; Recktenwald, J.; Kuhle, V.; Herold, S.; Hensel, M.; Schmidt, H. The Shiga toxin 1-converting bacteriophage BP-4795 encodes an NleA-like type III effector protein. J. Bacteriol. 2005, 187, 8494-8498. [CrossRef] [PubMed]

52. Yokoyama, K.; Makino, K.; Kubota, Y.; Watanabe, M.; Kimura, S.; Yutsudo, C.H.; Kurokawa, K.; Ishii, K.; Hattori, M.; Tatsuno, I.; et al. Complete nucleotide sequence of the prophage VT1-Sakai carrying the Shiga toxin 1 genes of the enterohemorrhagic Escherichia coli O157:H7 strain derived from the Sakai outbreak. Gene 2000, 258, 127-139. [CrossRef] 
53. Strauch, E.; Hammerl, J.A.; Konietzny, A.; Schneiker-Bekel, S.; Arnold, W.; Goesmann, A.; Pühler, A.; Beutin, L. Bacteriophage 2851 is a prototype phage for dissemination of the Shiga toxin variant gene 2c in Escherichia coli O157:H7. Infect. Immun. 2008, 76, 5466-5477. [CrossRef]

54. Koch, C.; Hertwig, S.; Appel, B. Nucleotide sequence of the integration site of the temperate bacteriophage 6220, which carries the Shiga toxin gene $s t x_{1 \mathrm{ox} 3} . J$. Bacteriol. 2003, 185, 6463-6466. [CrossRef] [PubMed]

55. Creuzberg, K.; Köhler, B.; Hempel, H.; Schreier, P.; Jacobs, E.; Schmidt, H. Genetic structure and chromosomal integration site of the cryptic prophage CP-1639 encoding Shiga toxin 1. Microbiology 2005, 151, 941-950. [CrossRef]

56. Ogura, Y.; Ooka, T.; Asadulghani; Terajima, J.; Nougayrède, J.P.; Kurokawa, K.; Tashiro, K.; Tobe, T.; Nakayama, K.; Kuhara, S.; et al. Extensive genomic diversity and selective conservation of virulence-determinants in enterohemorrhagic Escherichia coli strains of O157 and non-O157 serotypes. Genome Biol. 2007, 8. [CrossRef]

57. Kulasekara, B.R.; Jacobs, M.; Zhou, Y.; Wu, Z.; Sims, E.; Saenphimmachak, C.; Rohmer, L.; Ritchie, J.M.; Radey, M.; McKevitt, M.; et al. Analysis of the genome of the Escherichia coli O157:H7 2006 spinach-associated outbreak isolate indicates candidate genes that may enhance virulence. Infect. Immun. 2009, 77, 3713-3721. [CrossRef] [PubMed]

58. Steyert, S.R.; Sahl, J.W.; Fraser, C.M.; Teel, L.D.; Scheutz, F.; Rasko, D.A. Comparative genomics and stx phage characterization of LEE-negative Shiga toxin-producing Escherichia coli. Front. Cell. Infect. Microbiol. 2012, 2, 133. [CrossRef]

59. Bai, X.; Fu, S.; Zhang, J.; Fan, R.; Xu, Y.; Sun, H.; He, X.; Xu, J.; Xiong, Y. Identification and pathogenomic analysis of an Escherichia coli strain producing a novel Shiga toxin 2 subtype. Sci. Rep. 2018, 8. [CrossRef] [PubMed]

60. Titz, B.; Häuser, R.; Engelbrecher, A.; Uetz, P. The Escherichia coli protein YjjG is a house-cleaning nucleotidase in vivo. FEMS Microbiol. Lett. 2007, 270, 49-57. [CrossRef] [PubMed]

61. Farrugia, D.N.; Elbourne, L.D.H.; Mabbutt, B.C.; Paulsen, I.T. A novel family of integrases associated with prophages and genomic islands integrated within the tRNA-dihydrouridine synthase A (dusA) gene. Nucleic Acids Res. 2015, 43, 4547-4557. [CrossRef]

62. Perna, N.T.; Iii, G.P.; Burland, V.; Mau, B.; Glasner, J.D.; Rose, D.J.; Mayhew, G.F.; Po, È.; Evans, P.S.; Gregor, J.; et al. Genome sequence of enterohaemorrhagic Escherichia coli O157:H7. Nature 2001, 409, 529-533. [CrossRef]

63. Vanderhaeghen, S.; Zehentner, B.; Scherer, S.; Neuhaus, K.; Ardern, Z. The novel EHEC gene asa overlaps the TEGT transporter gene in antisense and is regulated by $\mathrm{NaCl}$ and growth phase. Sci. Rep. 2018, 8, 17875. [CrossRef]

64. Lim, C.K.; Hassan, K.A.; Penesyan, A.; Loper, J.E.; Paulsen, I.T. The effect of zinc limitation on the transcriptome of Pseudomonas protegens Pf-5. Environ. Microbiol. 2013, 15, 702-715. [CrossRef] [PubMed]

65. Fogg, P.C.M.; Saunders, J.R.; Mccarthy, A.J.; Allison, H.E. Cumulative effect of prophage burden on Shiga toxin production in Escherichia coli. Microbiology 2012, 158, 488-497. [CrossRef] [PubMed]

66. Allison, H.E.; Sergeant, M.J.; James, C.E.; Saunders, J.R.; Smith, D.L.; Sharp, R.J.; Marks, T.S.; McCarthy, A.J. Immunity profiles of wild-type and recombinant Shiga-like toxin-encoding bacteriophages and characterization of novel double lysogens. Infect. Immun. 2003, 71, 3409-3418. [CrossRef] [PubMed]

67. Fogg, P.C.M.; Gossage, S.M.; Smith, D.L.; Saunders, J.R.; McCarthy, A.J.; Allison, H.E. Identification of multiple integration sites for Stx-phage $\Phi 24 \mathrm{~B}$ in the Escherichia coli genome, description of a novel integrase and evidence for a functional anti-repressor. Microbiology 2007, 153, 4098-4110. [CrossRef]

68. Ogura, Y.; Mondal, S.I.; Islam, M.R.; Mako, T.; Arisawa, K.; Katsura, K.; Ooka, T.; Gotoh, Y.; Murase, K.; Ohnishi, M.; et al. The Shiga toxin 2 production level in enterohemorrhagic Escherichia coli O157:H7 is correlated with the subtypes of toxin-encoding phage. Sci. Rep. 2015, 5, 16663. [CrossRef]

69. Kimmitt, P.T.; Harwood, C.R.; Barer, M.R. Toxin gene expression by Shiga toxin-producing Escherichia coli: The role of antibiotics and the bacterial SOS response. Emerg. Infect. Dis. 2000, 6, 458-465. [CrossRef] [PubMed]

70. Wagner, P.L.; Livny, J.; Neely, M.N.; Acheson, D.W.K.; Friedman, D.I.; Waldor, M.K. Bacteriophage control of Shiga toxin 1 production and release by Escherichia coli. Mol. Microbiol. 2002, 44, 957-970. [CrossRef]

71. Lenzi, L.J.; Lucchesi, P.M.A.; Medico, L.; Burgán, J.; Krüger, A. Effect of the food additives sodium citrate and disodium phosphate on shiga toxin-producing Escherichia coli and production of stx-phages and Shiga toxin. Front. Microbiol. 2016, 7, 992. [CrossRef]

72. Imamovic, L.; Muniesa, M. Characterizing RecA-independent induction of Shiga toxin2-encoding phages by EDTA treatment. PLoS ONE 2012, 7, e32393. [CrossRef] [PubMed]

73. Maiques, E.; Úbeda, C.; Campoy, S.; Salvador, N.; Lasa, Í.; Novick, R.P.; Barbé, J.; Penadés, J.R. $\beta$-lactam antibiotics induce the SOS response and horizontal transfer of virulence factors in Staphylococcus aureus. J. Bacteriol. 2006, 188, 2726-2729. [CrossRef]

74. Köhler, B.; Karch, H.; Schmidt, H. Antibacterials that are used as growth promoters in animal husbandry can affect the release of Shiga-toxin-2-converting bacteriophages and Shiga toxin 2 from Escherichia coli strains. Microbiology 2000, 146, 1085-1090. [CrossRef] [PubMed]

75. Łoś, J.M.; Łoś, M.; Wegrzyn, G.; Wegrzyn, A. Differential efficiency of induction of various lambdoid prophages responsible for production of Shiga toxins in response to different induction agents. Microb. Pathog. 2009, 47, 289-298. [CrossRef] [PubMed]

76. Łoś, J.M.; Łoś, M.; Wȩgrzyn, A.; Wȩgrzyn, G. Hydrogen peroxide-mediated induction of the Shiga toxin-converting lambdoid prophage ST2-8624 in Escherichia coli O157:H7. FEMS Immunol. Med. Microbiol. 2010, 58, 322-329. [CrossRef]

77. Fang, Y.; Mercer, R.G.; McMullen, L.M.; Gänzle, M.G. Induction of Shiga toxin-encoding prophage by abiotic environmental stress in food. Appl. Environ. Microbiol. 2017, 83, e01378-17. [CrossRef] 
78. Nejman, B.; Nadratowska-Wesołowska, B.; Szalewska-Pałasz, A.; Wȩgrzyn, A.; Wȩgrzyn, G. Replication of plasmids derived from Shiga toxin-converting bacteriophages in starved Escherichia coli. Microbiology 2011, 157, 220-233. [CrossRef]

79. Muniesa, M.; (Department of Genetics, Microbiology and Statistics, University of Barcelona, Barcelona, Spain). Personal communication, 2021.

80. Balasubramanian, S.; Osburne, M.S.; BrinJones, H.; Tai, A.K.; Leong, J.M. Prophage induction, but not production of phage particles, is required for lethal disease in a microbiome-replete murine model of enterohemorrhagic E. coli infection. PLoS Pathog. 2019, 15, 1-27. [CrossRef]

81. Yokoyama, K.; Horii, T.; Yamashino, T.; Hashikawa, S.; Barua, S.; Hasegawa, T.; Watanabe, H.; Ohta, M. Production of Shiga toxin by Escherichia coli measured with reference to the membrane vesicle-associated toxins. FEMS Microbiol. Lett. 2000, 192, 139-144. [CrossRef]

82. Kolling, G.L.; Matthews, K.R. Export of virulence genes and Shiga toxin by membrane vesicles of Escherichia coli O157:H7. Appl. Environ. Microbiol. 1999, 65, 1843-1848. [CrossRef]

83. Bielaszewska, M.; Rüter, C.; Bauwens, A.; Greune, L.; Jarosch, K.A.; Steil, D.; Zhang, W.; He, X.; Lloubes, R.; Fruth, A.; et al. Host cell interactions of outer membrane vesicle-associated virulence factors of enterohemorrhagic Escherichia coli O157: Intracellular delivery, trafficking and mechanisms of cell injury. PLoS Pathog. 2017, 13. [CrossRef] [PubMed]

84. Kunsmann, L.; Ruter, C.; Bauwens, A.; Greune, L.; Gluder, M.; Kemper, B.; Fruth, A.; Wai, S.N.; He, X.; Lloubes, R.; et al. Virulence from vesicles: Novel mechanisms of host cell injury by Escherichia coli O104:H4 outbreak strain. Sci. Rep. 2015, 5, 13252. [CrossRef] [PubMed]

85. Khalil, R.K.S.; Skinner, C.; Patfield, S.; He, X. Phage-mediated Shiga toxin (Stx) horizontal gene transfer and expression in non-Shiga toxigenic Enterobacter and Escherichia coli strains. Pathog. Dis. 2016, 74. [CrossRef]

86. Eichhorn, I.; Heidemanns, K.; Ulrich, R.G.; Schmidt, H.; Semmler, T.; Fruth, A.; Bethe, A.; Goulding, D.; Pickard, D.; Karch, H.; et al. Lysogenic conversion of atypical enteropathogenic Escherichia coli (aEPEC) from human, murine, and bovine origin with bacteriophage $\Phi 3538 \Delta s t x 2::$ cat proves their enterohemorrhagic E. coli (EHEC) progeny. Int. J. Med. Microbiol. 2018, 308, 890-898. [CrossRef]

87. Schmidt, H.; Montag, M.; Bockemuhl, J.; Heesemann, J.; Karch, H. Shiga-like toxin II-related cytotoxins in Citrobacter freundii strains from humans and beef samples. Infect. Immun. 1993, 61, 534-543. [CrossRef]

88. Paton, A.W.; Paton, J.C. Enterobacter cloacae producing a Shiga-like toxin II-related cytotoxin associated with a case of hemolyticuremic syndrome. J. Clin. Microbiol. 1996, 34, 463-465. [CrossRef]

89. Tóth, I.; Sváb, D.; Bálint, B.; Brown-Jaque, M.; Maróti, G. Comparative analysis of the Shiga toxin converting bacteriophage first detected in Shigella sonnei. Infect. Genet. Evol. 2016, 37, 150-157. [CrossRef] [PubMed]

90. Palma-Martínez, I.; Guerrero-Mandujano, A.; Ruiz-Ruiz, M.J.; Hernández-Cortez, C.; Molina-López, J.; Bocanegra-García, V.; Castro-Escarpulli, G. Active shiga-like toxin produced by some Aeromonas spp., isolated in Mexico City. Front. Microbiol. 2016, 7. [CrossRef] [PubMed]

91. Grau-Leal, F.; Quirós, P.; Martínez-Castillo, A.; Muniesa, M. Free Shiga toxin 1-encoding bacteriophages are less prevalent than Shiga toxin 2 phages in extraintestinal environments. Environ. Microbiol. 2015, 17, 4790-4801. [CrossRef]

92. Imamovic, L.; Ballesté, E.; Martínez-Castillo, A.; García-Aljaro, C.; Muniesa, M. Heterogeneity in phage induction enables the survival of the lysogenic population. Environ. Microbiol. 2016, 18, 957-969. [CrossRef]

93. Glinkowska, M.; Łoś, J.M.; Szambowska, A.; Czyż, A.; Całkiewicz, J.; Herman-Antosiewicz, A.; Wróbel, B.; Wȩgrzyn, G.; Węgrzyn, A.; Łoś, M. Influence of the Escherichia coli oxyR gene function on $\lambda$ prophage maintenance. Arch. Microbiol. 2010, 192, 673-683. [CrossRef]

94. Loś, J.M.; Loś, M.; Wȩgrzyn, A.; Wȩgrzyn, G. Altruism of Shiga toxin-producing Escherichia coli: Recent hypothesis versus experimental results. Front. Cell. Infect. Microbiol. 2013, 4, 1-8. [CrossRef]

95. Hernandez-Doria, J.D.; Sperandio, V. Bacteriophage transcription factor Cro regulates virulence gene expression in enterohemorrhagic Escherichia coli. Cell Host Microbe 2018, 23, 607-617.e6. [CrossRef]

96. Unkmeir, A.; Schmidt, H. Structural analysis of phage-borne stx genes and their flanking sequences in Shiga toxin-producing Escherichia coli and Shigella dysenteriae type 1 strains. Infect. Immun. 2000, 68, 4856-4864. [CrossRef] [PubMed]

97. Herold, S.; Siebert, J.; Huber, A.; Schmidt, H. Global expression of prophage genes in Escherichia coli O157:H7 strain EDL933 in response to norfloxacin. Antimicrob. Agents Chemother. 2005, 49, 931-944. [CrossRef] [PubMed]

98. Polzin, S.; Huber, C.; Eylert, E.; Elsenhans, I.; Eisenreich, W.; Schmidt, H. Growth media simulating ileal and colonic environments affect the intracellular proteome and carbon fluxes of enterohemorrhagic Escherichia coli O157: H7 strain EDL933. Appl. Environ. Microbiol. 2013, 79, 3703-3715. [CrossRef] [PubMed]

99. Vimr, E.R. Unified theory of bacterial sialometabolism: How and why bacteria metabolize host sialic acids. ISRN Microbiol. 2013, 2013, 1-26. [CrossRef] [PubMed]

100. Rangel, A.; Steenbergen, S.M.; Vimr, E.R. Unexpected diversity of Escherichia coli sialate O-acetyl esterase NanS. J. Bacteriol. 2016, 198, 2803-2809. [CrossRef]

101. Nübling, S.; Eisele, T.; Stöber, H.; Funk, J.; Polzin, S.; Fischer, L.; Schmidt, H. Bacteriophage $933 W$ encodes a functional esterase downstream of the Shiga toxin 2a operon. Int. J. Med. Microbiol. 2014, 304, 269-274. [CrossRef] 
102. Saile, N.; Voigt, A.; Kessler, S.; Stressler, T.; Klumpp, J.; Fischer, L.; Schmidt, H. Escherichia coli O157:H7 strain EDL933 harbors multiple functional prophage-associated genes necessary for the utilization of 5- $\mathrm{N}$-acetyl-9-O-acetyl neuraminic acid as a growth substrate. Appl. Environ. Microbiol. 2016, 82, 5940-5950. [CrossRef]

103. Saile, N.; Schwarz, L.; Eissenberger, K.; Klumpp, J.; Fricke, F.W.; Schmidt, H. Growth advantage of Escherichia coli O104:H4 strains on 5-N-acetyl-9-O-acetyl neuraminic acid as a carbon source is dependent on heterogeneous phage-borne nanS-p esterases. Int. J. Med. Microbiol. 2018, 308, 459-468. [CrossRef]

104. Franke, B.; Veses-Garcia, M.; Diederichs, K.; Allison, H.; Rigden, D.J.; Mayans, O. Structural annotation of the conserved carbohydrate esterase vb_24B_21 from Shiga toxin-encoding bacteriophage Ф24B. J. Struct. Biol. 2020, 212, 107596. [CrossRef]

105. Feuerbaum, S.; Saile, N.; Pohlentz, G.; Müthing, J.; Schmidt, H. De-O-Acetylation of mucin-derived sialic acids by recombinant NanS-p esterases of Escherichia coli O157:H7 strain EDL933. Int. J. Med. Microbiol. 2018, 308, 1113-1120. [CrossRef]

106. Boraston, A.B.; Bolam, D.N.; Gilbert, H.J.; Davies, G.J. Carbohydrate-binding modules: Fine-tuning polysaccharide recognition. Biochem. J. 2004, 382, 769-781. [CrossRef]

107. Gilbert, H.J.; Knox, J.P.; Boraston, A.B. Advances in understanding the molecular basis of plant cell wall polysaccharide recognition by carbohydrate-binding modules. Curr. Opin. Struct. Biol. 2013, 23, 669-677. [CrossRef] [PubMed]

108. Kulikov, E.E.; Golomidova, A.K.; Prokhorov, N.S.; Ivanov, P.A.; Letarov, A.V. High-throughput LPS profiling as a tool for revealing of bacteriophage infection strategies. Sci. Rep. 2019, 9, 2958. [CrossRef] [PubMed]

109. Prokhorov, N.S.; Riccio, C.; Zdorovenko, E.L.; Shneider, M.M.; Browning, C.; Knirel, Y.A.; Leiman, P.G.; Letarov, A.V. Function of bacteriophage G7C esterase tailspike in host cell adsorption. Mol. Microbiol. 2017, 105, 385-398. [CrossRef] [PubMed]

110. Kulikov, E.E.; Majewska, J.; Prokhorov, N.S.; Golomidova, A.K.; Tatarskiy, E.V.; Letarov, A.V. Effect of O-acetylation of O antigen of Escherichia coli lipopolysaccharide on the nonspecific barrier function of the outer membrane. Microbiology 2017, 86, 310-316. [CrossRef]

111. Pickard, D.; Toribio, A.L.; Petty, N.K.; Van Tonder, A.; Yu, L.; Goulding, D.; Barrell, B.; Rance, R.; Harris, D.; Wetter, M.; et al. A conserved acetyl esterase domain targets diverse bacteriophages to the Vi capsular receptor of Salmonella enterica serovar typhi. J. Bacteriol. 2010, 192, 5746-5754. [CrossRef] [PubMed]

112. Casjens, S.R.; Molineux, I.J. Short noncontractile tail machines: Adsorption and DNA delivery by podoviruses. Adv. Exp. Med. Biol. 2012, 726, 143-179. [CrossRef] [PubMed]

113. Josenhans, C.; Müthing, J.; Elling, L.; Bartfeld, S.; Schmidt, H. How bacterial pathogens of the gastrointestinal tract use the mucosal glyco-code to harness mucus and microbiota: New ways to study an ancient bag of tricks. Int. J. Med. Microbiol. 2020, 310. [CrossRef]

114. Strockbine, N.A.; Marques, L.R.M.; Newland, J.W.; Smith, H.W.; Holmes, R.K.; O'brien, A.D. Two toxin-converting phages from Escherichia coli O157:H7 strain 933 encode antigenically distinct toxins with similar biologic activities. Infect. Immun. 1986, 53, 135-140. [CrossRef] [PubMed]

115. Scheutz, F.; Teel, L.D.; Beutin, L.; Piérard, D.; Buvens, G.; Karch, H.; Mellmann, A.; Caprioli, A.; Tozzoli, R.; Morabito, S.; et al. Multicenter evaluation of a sequence-based protocol for subtyping Shiga toxins and standardizing Stx nomenclature. J. Clin. Microbiol. 2012, 50, 2951-2963. [CrossRef] [PubMed]

116. Friedrich, A.W.; Bielaszewska, M.; Zhang, W.L.; Pulz, M.; Kuczius, T.; Ammon, A.; Karch, H. Escherichia coli harboring shiga toxin 2 gene variants: Frequency and association with clinical symptoms. J. Infect. Dis. 2002, 185, 74-84. [CrossRef]

117. Persson, S.; Olsen, K.E.P.; Ethelberg, S.; Scheutz, F. Subtyping method for Escherichia coli Shiga toxin (Verocytotoxin) 2 variants and correlations to clinical manifestations. J. Clin. Microbiol. 2007, 45, 2020-2024. [CrossRef] [PubMed]

118. Fuller, C.A.; Pellino, C.A.; Flagler, M.J.; Strasser, J.E.; Weiss, A.A. Shiga toxin subtypes display dramatic differences in potency. Infect. Immun. 2011, 79, 1329-1337. [CrossRef] [PubMed]

119. Fitzgerald, S.F.; Beckett, A.E.; Palarea-Albaladejo, J.; McAteer, S.; Shaaban, S.; Morgan, J.; Ahmad, N.I.; Young, R.; Mabbott, N.A.; Morrison, L.; et al. Shiga toxin sub-type 2a increases the efficiency of Escherichia coli $\mathrm{O} 157$ transmission between animals and restricts epithelial regeneration in bovine enteroids. PLoS Pathog. 2019, 15. [CrossRef]

120. Lacher, D.W.; Gangiredla, J.; Patel, I.; Elkins, C.A.; Feng, P.C.H. Use of the Escherichia coli identification microarray for characterizing the health risks of Shiga toxin-producing Escherichia coli isolated from foods. J. Food Prot. 2016, 79, 1656-1662. [CrossRef] [PubMed]

121. Martin, C.C.; Svanevik, C.S.; Lunestad, B.T.; Sekse, C.; Johannessen, G.S. Isolation and characterisation of Shiga toxin-producing Escherichia coli from Norwegian bivalves. Food Microbiol. 2019, 84, 103268. [CrossRef]

122. Steinberg, K.M.; Levin, B.R. Grazing protozoa and the evolution of the Escherichia coli O157:H7 Shiga toxin-encoding prophage. Proc. R. Soc. B Biol. Sci. 2007, 274, 1921-1929. [CrossRef]

123. Lainhart, W.; Stolfa, G.; Koudelka, G.B. Shiga toxin as a bacterial defense against a eukaryotic predator, Tetrahymena thermophila. J. Bacteriol. 2009, 191, 5116-5122. [CrossRef]

124. Schmidt, C.E.; Shringi, S.; Besser, T.E. Protozoan predation of Escherichia coli O157: H7 Is unaffected by the carriage of Shiga toxin-encoding bacteriophages. PLoS ONE 2016, 11. [CrossRef] [PubMed]

125. Veses-Garcia, M.; Liu, X.; Rigden, D.J.; Kenny, J.G.; McCarthy, A.J.; Allison, H.E. Transcriptomic analysis of Shiga-toxigenic bacteriophage carriage reveals a profound regulatory effect on acid resistance in Escherichia coli. Appl. Environ. Microbiol. 2015, 81, 8118-8125. [CrossRef] 
126. Berger, P.; Kouzel, I.U.; Berger, M.; Haarmann, N.; Dobrindt, U.; Koudelka, G.B.; Mellmann, A. Carriage of Shiga toxin phage profoundly affects Escherichia coli gene expression and carbon source utilization. BMC Genom. 2019, 20, 504. [CrossRef]

127. Su, L.K.; Lu, C.P.; Wang, Y.; Cao, D.M.; Sun, J.H.; Yan, Y.X. Lysogenic infection of a Shiga toxin 2-converting bacteriophage changes host gene expression, enhances host acid resistance and motility. Mol. Biol. 2010, 44, 60-73. [CrossRef]

128. Tozzoli, R.; Grande, L.; Michelacci, V.; Fioravanti, R.; Gally, D.; Xu, X.; La Ragione, R.; Anjum, M.; Wu, G.; Caprioli, A.; et al. Identification and characterization of a peculiar $v t \times 2$-converting phage frequently present in verocytotoxin-producing Escherichia coli $\mathrm{O} 157$ isolated from human infections. Infect. Immun. 2014, 82, 3023-3032. [CrossRef] [PubMed]

129. Xu, X.; McAteer, S.P.; Tree, J.J.; Shaw, D.J.; Wolfson, E.B.K.; Beatson, S.A.; Roe, A.J.; Allison, L.J.; Chase-Topping, M.E.; Mahajan, A.; et al. Lysogeny with Shiga toxin 2-encoding bacteriophages represses type III secretion in enterohemorrhagic Escherichia coli. PLoS Pathog. 2012, 8. [CrossRef] [PubMed]

130. Schmidt, H.; Bielaszewska, M.; Karch, H. Transduction of enteric Escherichia coli isolates with a derivative of Shiga toxin 2encoding bacteriophage $\varphi 3538$ isolated from Escherichia coli O157:H7. Appl. Environ. Microbiol. 1999, 65, 3855-3861. [CrossRef] [PubMed]

131. Nataro, J.P.; Kaper, J.B. Diarrheagenic Escherichia coli. Clin. Microbiol. Rev. 1998, 11, 142-201. [CrossRef]

132. De Jonge, R.; Takumi, K.; Ritmeester, W.S.; Van Leusden, F.M. The adaptive response of Escherichia coli O157 in an environment with changing pH. J. Appl. Microbiol. 2003, 94, 555-560. [CrossRef] [PubMed]

133. Bergholz, T.M.; Whittam, T.S. Variation in acid resistance among enterohaemorrhagic Escherichia coli in a simulated gastric environment. J. Appl. Microbiol. 2007, 102, 352-362. [CrossRef]

134. Mitsunaka, S.; Sudo, N.; Sekine, Y. Lysogenisation of shiga toxin-encoding bacteriophage represses cell motility. J. Gen. Appl. Microbiol. 2018, 64, 34-41. [CrossRef] [PubMed]

135. Karch, H.; Denamur, E.; Dobrindt, U.; Finlay, B.B.; Hengge, R.; Johannes, L.; Ron, E.Z.; Tonjum, T.; Sansonetti, P.J.; Vicente, M. The enemy within us: Lessons from the 2011 European Escherichia coli O104:H4 outbreak. EMBO Mol. Med. 2012, 4, 841-848. [CrossRef]

136. Waters, S.A.; McAteer, S.P.; Kudla, G.; Pang, I.; Deshpande, N.P.; Amos, T.G.; Leong, K.W.; Wilkins, M.R.; Strugnell, R.; Gally, D.L.; et al. Small RNA interactome of pathogenic E. coli revealed through crosslinking of RNaseE. EMBO J. 2017, 36, 374-387. [CrossRef] [PubMed]

137. Sudo, N.; Soma, A.; Muto, A.; Iyoda, S.; Suh, M.; Kurihara, N.; Abe, H.; Tobe, T.; Ogura, Y.; Hayashi, T.; et al. A novel small regulatory RNA enhances cell motility in enterohemorrhagic Escherichia coli. J. Gen. Appl. Microbiol. 2014, 60, 44-50. [CrossRef] [PubMed]

138. Schnaitman, C.; Smith, D.; de Salsas, M.F. Temperate bacteriophage which causes the production of a new major outer membrane protein by Escherichia coli. J. Virol. 1975, 15, 1121-1130. [CrossRef]

139. Castillo-Keller, M.; Vuong, P.; Misra, R. Novel mechanism of Escherichia coli porin regulation. J. Bacteriol. 2006, 188, 576-586. [CrossRef]

140. Bartel, D.P. Digital quantitative analysis of microRNA in single cell based on ligation-depended polymerase colony (Polony). Cell 2004, 116, 281-297. [CrossRef]

141. Bloch, S.; Węgrzyn, A.; Węgrzyn, G.; Nejman-Faleńczyk, B. Small and smaller-sRNAs and microRNAs in the regulation of toxin gene expression in prokaryotic cells: A mini-review. Toxins 2017, 9, 181. [CrossRef]

142. Dydecka, A.; Nejman-Faleńczyk, B.; Bloch, S.; Topka, G.; Necel, A.; Donaldson, L.W.; Węgrzyn, G.; Węgrzyn, A. Roles of orf60a and orf61 in development of bacteriophages $\lambda$ and $\Phi 24 \mathrm{~b}$. Viruses 2018, 10, 553. [CrossRef]

143. Dydecka, A.; Bloch, S.; Rizvi, A.; Perez, S.; Nejman-Falenczyk, B.; Topka, G.; Gasior, T.; Necel, A.; Wegrzyn, G.; Donaldson, L.W.; et al. Bad phages in good bacteria: Role of the mysterious orf63 of $\lambda$ and Shiga toxin-converting $\Phi 24 \mathrm{~B}$ bacteriophages. Front. Microbiol. 2017, 8, 1618. [CrossRef]

144. Zdrojewska, K.; Dydecka, A.; Nejman-Faleńczyk, B.; Topka, G.; Necel, A.; Wegrzyn, A.; Wegrzyn, G.; Bloch, S. Role of orf73 in the development of lambdoid bacteriophages during infection of the Escherichia coli host. Acta Biochim. Pol. 2019, 66, 589-596. [CrossRef]

145. Dydecka, A.; Bloch, S.; Necel, A.; Topka, G.; Węgrzyn, A.; Tong, J.; Donaldson, L.W.; Węgrzyn, G.; Nejman-Faleńczyk, B. The ea22 gene of lambdoid phages: Preserved prolysogenic function despite of high sequence diversity. Virus Genes 2020, 56, 266-277. [CrossRef] [PubMed]

146. Tong, J.; Nejman-Faleńczyk, B.; Bloch, S.; Wȩgrzyn, A.; Wȩgrzyn, G.; Donaldson, L.W. Ea22 proteins from lambda and Shiga toxinproducing bacteriophages balance structural diversity with functional similarity. ACS Omega 2020, 5, 12236-12244. [CrossRef]

147. Jubelin, G.; Desvaux, M.; Schüller, S.; Etienne-Mesmin, L.; Muniesa, M.; Blanquet-Diot, S. Modulation of enterohaemorrhagic Escherichia coli survival and virulence in the human gastrointestinal tract. Microorganisms 2018, 6, 115. [CrossRef]

148. Melton-Celsa, A.R. Shiga toxin (Stx) classification, structure, and function. Microbiol. Spectr. 2014, 2. [CrossRef] [PubMed]

149. Poolpol, K.; Orth-Höller, D.; Speth, C.; Zipfel, P.F.; Skerka, C.; de Córdoba, S.R.; Brockmeyer, J.; Bielaszewska, M.; Würzner, R. Interaction of Shiga toxin 2 with complement regulators of the factor H protein family. Mol. Immunol. 2014, 58, 77-84. [CrossRef] [PubMed]

150. Navarro, F.; Muniesa, M. Phages in the human body. Front. Microbiol. 2017, 8, 1-7. [CrossRef] 
151. Górski, A.; Miedzybrodzki, R.; Borysowski, J.; Dabrowska, K.; Wierzbicki, P.; Ohams, M.; Korczak-Kowalska, G.; OlszowskaZaremba, N.; Łusiak-Szelachowska, M.; Kłak, M.; et al. Phage as a modulator of immune responses: Practical implications for phage therapy. Adv. Virus Res. 2012, 83, 41-71. [CrossRef]

152. Bentancor, L.V.; Mejías, M.P.; Pinto, A.; Bilen, M.F.; Meiss, R.; Rodriguez-Galán, M.C.; Baez, N.; Pedrotti, L.P.; Goldstein, J.; Ghiringhelli, P.D.; et al. Promoter sequence of shiga toxin 2 (Stx2) is recognized in vivo, leading to production of biologically active Stx2. MBio 2013, 4, e00501-13. [CrossRef] [PubMed]

153. Lengeling, A.; Mahajan, A.; Gally, D.L. Bacteriophages as pathogens and immune modulators? MBio 2013, 4. [CrossRef]

154. Del Cogliano, M.E.; Pinto, A.; Goldstein, J.; Zotta, E.; Ochoa, F.; Fernández-Brando, R.J.; Muniesa, M.; Ghiringhelli, P.D.; Palermo, M.S.; Bentancor, L.V. Relevance of bacteriophage $933 \mathrm{~W}$ in the development of hemolytic uremic syndrome (HUS). Front. Microbiol. 2018. [CrossRef]

155. Górski, A.; Wazna, E.; Dabrowska, B.-W.; Dabrowska, K.; Switała-Jeleń, K.; Miedzybrodzki, R. Bacteriophage translocation. FEMS Immunol. Med. Microbiol. 2006, 46, 313-319. [CrossRef]

156. Brown-Jaque, M.; Muniesa, M.; Navarro, F. Bacteriophages in clinical samples can interfere with microbiological diagnostic tools. Sci. Rep. 2016, 6, 33000. [CrossRef] [PubMed]

157. Gobert, A.P.; Vareille, M.; Glasser, A.-L.; Hindré, T.; de Sablet, T.; Martin, C. Shiga toxin produced by enterohemorrhagic Escherichia coli inhibits PI3K/NF- $\mathrm{KB}$ signaling pathway in globotriaosylceramide-3-negative human intestinal epithelial cells. J. Immunol. 2007, 178, 8168-8174. [CrossRef]

158. Gobert, A.P.; Coste, A.; Guzman, C.A.; Vareille, M.; Hindré, T.; de Sablet, T.; Girardeau, J.P.; Martin, C. Modulation of chemokine gene expression by Shiga-toxin producing Escherichia coli belonging to various origins and serotypes. Microbes Infect. 2008, 10, 159-165. [CrossRef] [PubMed]

159. Robinson, C.M.; Sinclair, J.F.; Smith, M.J.; O’Brien, A.D. Shiga toxin of enterohemorrhagic Escherichia coli type O157:H7 promotes intestinal colonization. Proc. Natl. Acad. Sci. USA 2006, 103, 9667-9672. [CrossRef]

160. Menge, C.; Wieler, L.H.; Schlapp, T.; Baljer, G. Shiga toxin 1 from Escherichia coli blocks activation and proliferation of bovine lymphocyte subpopulations in vitro. Infect. Immun. 1999, 67, 2209-2217. [CrossRef] [PubMed]

161. Fauquet, C.M.; Fargette, D. International Committee on Taxonomy of Viruses and the 3142 unassigned species. Virol. J. 2005, 2, 64. [CrossRef] [PubMed]

162. Hatfull, G.F. Bacteriophage genomics. Curr. Opin. Microbiol. 2008, 11, 447-453. [CrossRef]

163. Ohnishi, M.; Kurokawa, K.; Hayashi, T. Diversification of Escherichia coli genomes: Are bacteriophages the major contributors? Trends Microbiol. 2001, 9, 481-485. [CrossRef]

164. Muniesa, M.; Colomer-Lluch, M.; Jofre, J. Could bacteriophages transfer antibiotic resistance genes from environmental bacteria to human-body associated bacterial populations? Mob. Genet. Elements 2013, 3, e25847. [CrossRef] [PubMed]

165. Datsenko, K.A.; Wanner, B.L. One-step inactivation of chromosomal genes in Escherichia coli K-12 using PCR products. Proc. Natl. Acad. Sci. USA 2000, 97, 6640-6645. [CrossRef]

166. Fillol-Salom, A.; Bacarizo, J.; Alqasmi, M.; Ciges-Tomas, J.R.; Martínez-Rubio, R.; Roszak, A.W.; Cogdell, R.J.; Chen, J.; Marina, A.; Penadés, J.R. Hijacking the hijackers: Escherichia coli pathogenicity islands redirect helper phage packaging for their own benefit. Mol. Cell 2019, 75, 1020-1030.e4. [CrossRef]

167. De Paepe, M.; Hutinet, G.; Son, O.; Amarir-Bouhram, J.; Schbath, S.; Petit, M.A. Temperate phages acquire DNA from defective prophages by relaxed homologous recombination: The role of Rad52-like recombinases. PLoS Genet. 2014, 10. [CrossRef]

168. Tormo-Más, M.Á.; Mir, I.; Shrestha, A.; Tallent, S.M.; Campoy, S.; Lasa, Í.; Barbé, J.; Novick, R.P.; Christie, G.E.; Penadés, J.R. Moonlighting bacteriophage proteins derepress staphylococcal pathogenicity islands. Nature 2010, 465, 779-782. [CrossRef] [PubMed]

169. Rodríguez-Rubio, L.; Serna, C.; Ares-Arroyo, M.; Matamoros, B.R.; Delgado-Blas, J.F.; Montero, N.; Bernabe-Balas, C.; Wedel, E.F.; Mendez, I.S.; Muniesa, M.; et al. Extensive antimicrobial resistance mobilization via multicopy plasmid encapsidation mediated by temperate phages. J. Antimicrob. Chemother. 2020. [CrossRef] [PubMed]

170. Asakura, M.; Hinenoya, A.; Alam, M.S.; Shima, K.; Zahid, S.H.; Shi, L.; Sugimoto, N.; Ghosh, A.N.; Ramamurthy, T.; Faruque, S.M.; et al. An inducible lambdoid prophage encoding cytolethal distending toxin (Cdt-I) and a type III effector protein in enteropathogenic Escherichia coli. Proc. Natl. Acad. Sci. USA 2007, 104, 14483-14488. [CrossRef]

171. Allué-Guardia, A.; García-Aljaro, C.; Muniesa, M. Bacteriophage-encoding cytolethal distending toxin type V gene induced from nonclinical Escherichia coli isolates. Infect. Immun. 2011, 79, 3262-3272. [CrossRef] [PubMed]

172. Sváb, D.; Horváth, B.; Maróti, G.; Dobrindt, U.; Tóth, I. Sequence variability of P2-like prophage genomes carrying the cytolethal distending toxin V operon in Escherichia coli O157. Appl. Environ. Microbiol. 2013, 79, 4958-4964. [CrossRef]

173. Barondess, J.J.; Beckwith, J. A bacterial virulence determinant encoded by lysogenic coliphage lambda. Nature 1990, 346, 871-874. [CrossRef]

174. Sandt, C.H.; Hopper, J.E.; Hill, C.W. Activation of prophage eib genes for immunoglobulin-binding proteins by genes from the IbrAB genetic island of Escherichia coli ECOR-9. J. Bacteriol. 2002, 184, 3640-3648. [CrossRef]

175. Loukiadis, E.; Nobe, R.; Herold, S.; Tramuta, C.; Ogura, Y.; Ooka, T.; Morabito, S.; Kérourédan, M.; Brugère, H.; Schmidt, H.; et al. Distribution, functional expression, and genetic organization of Cif, a phage-encoded type III-secreted effector from enteropathogenic and enterohemorrhagic Escherichia coli. J. Bacteriol. 2008, 190, 275-285. [CrossRef] [PubMed] 
176. Dahan, S.; Wiles, S.; La Ragione, R.M.; Best, A.; Woodward, M.J.; Stevens, M.P.; Shaw, R.K.; Chong, Y.; Knutton, S.; Phillips, A.; et al. EspJ is a prophage-carried type III effector protein of attaching and effacing pathogens that modulates infection dynamics. Infect. Immun. 2005, 73, 679-686. [CrossRef] [PubMed]

177. Tobe, T.; Beatson, S.A.; Taniguchi, H.; Abe, H.; Bailey, C.M.; Fivian, A.; Younis, R.; Matthews, S.; Marches, O.; Frankel, G.; et al. An extensive repetoire of type III secretion effectors in Escherichia coli $\mathrm{O} 157$ and the role of lambdoid phages in their dissemination. Proc. Natl. Acad. Sci. USA 2006, 103, 14941-14946. [CrossRef] [PubMed]

178. Marchés, O.; Wiles, S.; Dziva, F.; La Ragione, R.M.; Schüller, S.; Best, A.; Phillips, A.D.; Hartland, E.L.; Woodward, M.J.; Stevens, M.P.; et al. Characterization of two non-locus of enterocyte effacement-encoded type III-translocated effectors, NleC and NleD, in attaching and effacing pathogens. Infect. Immun. 2005, 73, 8411-8417. [CrossRef] [PubMed]

179. Wang, M.; Zeng, Z.; Jiang, F.; Zheng, Y.; Shen, H.; Macedo, N.; Sun, Y.; Sahin, O.; Li, G. Role of enterotoxigenic Escherichia coli prophage in spreading antibiotic resistance in a porcine-derived environment. Environ. Microbiol. 2020, 22, 4974-4984. [CrossRef]

180. Larrañaga, O.; Brown-Jaque, M.; Quirós, P.; Gómez-Gómez, C.; Blanch, A.R.; Rodríguez-Rubio, L.; Muniesa, M. Phage particles harboring antibiotic resistance genes in fresh-cut vegetables and agricultural soil. Environ. Int. 2018, 115, 133-141. [CrossRef]

181. Gómez-Gómez, C.; Blanco-Picazo, P.; Brown-Jaque, M.; Quirós, P.; Rodríguez-Rubio, L.; Cerdà-Cuellar, M.; Muniesa, M. Infectious phage particles packaging antibiotic resistance genes found in meat products and chicken feces. Sci. Rep. 2019, 9, 13281. [CrossRef]

182. Shousha, A.; Awaiwanont, N.; Sofka, D.; Smulders, F.J.M.; Paulsen, P.; Szostak, M.P.; Humphrey, T.; Hilbert, F. Bacteriophages isolated from chicken meat and the horizontal transfer of antimicrobial resistance genes. Appl. Environ. Microbiol. 2015, 81, 4600-4606. [CrossRef] [PubMed]

183. Blanco-Picazo, P.; Roscales, G.; Toribio-Avedillo, D.; Gómez-Gómez, C.; Avila, C.; Ballesté, E.; Muniesa, M.; Rodríguez-Rubio, L. Antibiotic resistance genes in phage particles from antarctic and mediterranean seawater ecosystems. Microorganisms 2020, 8, 1293. [CrossRef] [PubMed]

184. Zechner, V.; Sofka, D.; Paulsen, P.; Hilbert, F. Antimicrobial resistance in Escherichia coli and resistance genes in coliphages from a small animal clinic and in a patient dog with chronic urinary tract infection. Antibiotics 2020, 9, 652. [CrossRef] [PubMed]

185. Hilbert, M.; Csadek, I.; Auer, U.; Hilbert, F. Antimicrobial resistance-transducing bacteriophages isolated from surfaces of equine surgery clinics-A pilot study. Eur. J. Microbiol. Immunol. 2017, 7, 296-302. [CrossRef]

186. Liu, J.; Liu, P.; Feng, F.; Zhang, J.; Li, F.; Wang, M.; Sun, Y. Evaluation of potential ARG packaging by two environmental T7-like phage during phage-host interaction. Viruses 2020, 12, 1060. [CrossRef]

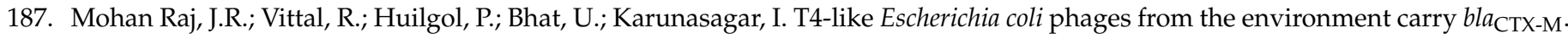
Lett. Appl. Microbiol. 2018, 67, 9-14. [CrossRef]

188. Billard-Pomares, T.; Fouteau, S.; Jacquet, M.E.; Roche, D.; Barbe, V.; Castellanos, M.; Bouet, J.Y.; Cruveiller, S.; Médigue, C.; Blanco, J.; et al. Characterization of a P1-like bacteriophage carrying an SHV-2 extended-spectrum $\beta$-Lactamase from an Escherichia coli strain. Antimicrob. Agents Chemother. 2014, 58, 6550-6557. [CrossRef]

189. Thierauf, A.; Perez, G.; Maloy, A.S. Generalized transduction. Methods Mol. Biol. 2009, 501, 267-286. [CrossRef]

190. Brown-Jaque, M.; Calero-Cáceres, W.; Muniesa, M. Transfer of antibiotic-resistance genes via phage-related mobile elements. Plasmid 2015, 79, 1-7. [CrossRef]

191. Brown-Jaque, M.; Calero-Cáceres, W.; Espinal, P.; Rodríguez-Navarro, J.; Miró, E.; González-López, J.J.; Cornejo, T.; Hurtado, J.C.; Navarro, F.; Muniesa, M. Antibiotic resistance genes in phage particles isolated from human faeces and induced from clinical bacterial isolates. Int. J. Antimicrob. Agents 2018, 51, 434-442. [CrossRef]

192. Colomer-Lluch, M.; Jofre, J.; Muniesa, M. Antibiotic resistance genes in the bacteriophage DNA fraction of environmental samples. PLoS ONE 2011, 6, e17549. [CrossRef] [PubMed]

193. Chen, J.; Quiles-Puchalt, N.; Chiang, Y.N.; Bacigalupe, R.; Fillol-Salom, A.; Chee, M.S.J.; Fitzgerald, J.R.; Penadés, J.R. Genome hypermobility by lateral transduction. Science 2018, 362, 207-212. [CrossRef] [PubMed]

194. Brown-Jaque, M.; Oyarzun, L.R.; Cornejo-Sánchez, T.; Martín-Gómez, M.T.; Gartner, S.; de Gracia, J.; Rovira, S.; Alvarez, A.; Jofre, J.; González-López, J.J.; et al. Detection of bacteriophage particles containing antibiotic resistance genes in the sputum of cystic fibrosis patients. Front. Microbiol. 2018, 9, 856. [CrossRef] [PubMed]

195. Ragunathan, P.T.; Vanderpool, C.K. Cryptic-prophage-encoded small protein DicB protects Escherichia coli from phage infection by inhibiting inner membrane receptor proteins. J. Bacteriol. 2019, 201. [CrossRef] [PubMed]

196. Wang, X.; Kim, Y.; Ma, Q.; Hoon Hong, S.; Pokusaeva, K.; Sturino, J.M.; Wood, T.K. Cryptic prophages help bacteria cope with adverse environments. Nat. Commun. 2010. [CrossRef]

197. Mehta, P.; Casjens, S.; Krishnaswamy, S. Analysis of the lambdoid prophage element e14 in the E. coli K-12 genome. BMC Microbiol. 2004, 4, 4. [CrossRef] [PubMed]

198. Tetz, G.; Brown, S.M.; Hao, Y.; Tetz, V. Type 1 diabetes: An association between autoimmunity, the dynamics of gut amyloidproducing E. coli and their phages. Sci. Rep. 2019, 9. [CrossRef]

199. Uhlich, G.A.; Chen, C.Y.; Cottrell, B.J.; Hofmann, C.S.; Dudley, E.G.; Strobaugh, T.P.; Nguyen, L.H. Phage insertion in $m l r A$ and variations in rpoS limit curli expression and biofilm formation in Escherichia coli serotype O157: H7. Microbiology 2013, 159, 1586-1596. [CrossRef] 